\title{
Assessment of groundwater quality in hard rock aquifer of central Telangana state for drinking and agriculture purposes
}

\author{
Annadasankar Roy ${ }^{1} \cdot$ Tirumalesh Keesari $^{1}$ [D $\cdot$ Hemant Mohokar ${ }^{1} \cdot$ Uday Kumar Sinha ${ }^{1} \cdot$ Sadasiva Bitra ${ }^{2}$
}

Received: 16 January 2018 / Accepted: 27 June 2018 / Published online: 24 July 2018

(c) The Author(s) 2018

\begin{abstract}
Quality assessment of groundwater for drinking and irrigation was evaluated in parts of Nalgonda district of Telangana state, India. The overall groundwater quality and the suitability to drinking and irrigation were evaluated by hydrochemical analysis of 78 groundwater samples. The water quality parameters were compared with that of the limits set by World Health Organisation (WHO) and Bureau of Indian Standards (BIS). Groundwater is found to be contaminated by fluoride and nitrate ions. The water quality indices (WQI) suggest that during pre-monsoon, $72.5 \%$ samples are suitable for drinking while $86.8 \%$ are suitable during post-monsoon. Indicators like sodium absorption ratio (SAR), electrical conductivity (EC), percent of sodium ( $\mathrm{Na} \%$ ), residual sodium carbonate (RSC), permeability index (PI), magnesium ratio (MR), residual sodium bicarbonate (RSBC), salinity hazard (SH), potential salinity (PS), soluble sodium percentage (SSP), and magnesium ratio (MR) were estimated for assessing the irrigation suitability of the groundwater samples. Wilcox, United States Salinity Laboratory diagrams (USSL diagram) and Doneen's chart infer that most of the samples are suitable for irrigation purpose and the suitability improves during post-monsoon. The geochemical evolution of the groundwater was also studied using Piper's and Chadha's diagrams. The major facies found in groundwater are $\mathrm{Na}-\mathrm{Mg}-\mathrm{HCO}_{3}-\mathrm{Cl}, \mathrm{Na}-\mathrm{Mg}-\mathrm{HCO}, \mathrm{Na}-\mathrm{HCO}_{3}$, $\mathrm{Mg}-\mathrm{Ca}-\mathrm{HCO}_{3}, \mathrm{Mg}-\mathrm{Na}-\mathrm{HCO}_{3}$ and $\mathrm{Na}-\mathrm{Cl}$. Rock-water interaction, ion exchange and evaporite dissolution were found to be the major geochemical processes governing the groundwater chemistry.
\end{abstract}

Keywords Water Quality Index · Hydrochemistry $\cdot$ Hard rock aquifers · Drinking and irrigation suitability

\section{Introduction}

Among the different sources of fresh water that can be used for drinking purpose, groundwater is the widely used resource due to quality and quantity considerations. Groundwater, in general, is not vulnerable to surface contamination since the contaminants are either decayed or diluted in unsaturated zone before reaching the water table while surface water is susceptible to contamination (Hounslow 1995; Sharma et al. 2017). Increased population and industry have led to a rapid decline in groundwater level due to over-exploitation and also resulted in quality deterioration. According to Ramesh and Elango (2012), the water

Tirumalesh Keesari

tiruh2o@gmail.com

1 Isotope Hydrology Section, Isotope and Radiation Application Division, Bhabha Atomic Research Centre, Trombay, Mumbai, India

2 DHAN Foundation, Hyderabad, India resources available in India are not sufficient to fulfil the needs of the whole population. The per capita water availability in India has dropped by 15\% from 2001 to 2011 (from 1816 cubic metres to 1545 cubic metres in 2011; Source: Ministry of statistics and programme implementation, India). This scenario is further severe in arid and semi-arid regions (Scanlon et al. 2006; Vasanthavigar et al. 2010). In this context, the groundwater quality assessment has become crucial in arid and semi-arid regions where rainfall is irregular and major water supplies to drinking and irrigation are met by groundwater.

Nalgonda district of Telangana state (India) falls under semi-arid region with an annual rainfall of $674 \mathrm{~mm}$ (CGWB 2013) and frequent draughts. The groundwater recharge is very less and occurs through fractures present in the hard rock formations. The groundwater quality is also reported to be poor due to the impact of chemical fertilisers, animal wastes and natural contaminants (Brindha et al. 2011; Keesari et al. 2014a, b; Venkateshwarlu et al. 2014). It is reported that parts of this district fall under semi-critical 
to over-exploited category (CGWB 2013). Many studies have reported the presence of high fluoride and salinity in groundwater of this region (Kota et al. 2016; Lakshmi et al. 2016; Venkateshwarlu et al. 2014). Heavy exploitation of groundwater was found to be reason for the quality deterioration in this district (Venkateshwarlu et al. 2014; Lakshmi et al. 2016). In the most recent studies, researchers found that rock-water interaction and evaporation are the main reasons for the water quality deterioration in this region (Das et al. 2017; Narsimha and Sudarshan 2017; Venkateshwarlu and Reddy 2017). Findings from studies by Vasu et al. (2017) and Adimalla and Venkatayogi (2018) also suggest the influence of rock-water interaction in addition to silicate weathering and reverse ion exchange towards the groundwater chemical evolution. In most instances, the groundwater was found to be unsuitable for household uses and marginal for irrigation purpose (Unnisa and Bi 2017). Most of the earlier studies were focused on the $\mathrm{F}^{-}$contamination and deterioration of water quality due to few parameters while studies on the overall chemistry of groundwater and its quality index are very limited. In this study, the overall geochemistry and water quality was studied using water quality index (WQI) in addition, suitability to drinking and irrigation was also evaluated. The suitability of the groundwater for domestic purpose was assessed in relation to WHO (2011) and BIS (2012) standards, while agricultural suitability was assessed by sodium absorption ratio (SAR), electrical conductivity (EC), percent of sodium ( $\mathrm{Na} \%$ ), residual sodium carbonate (RSC), permeability index (PI), magnesium ratio (MR), residual sodium bicarbonate (RSBC), salinity hazard (SH), potential salinity (PS), soluble sodium percentage (SSP), and magnesium ratio (MR). Chadda's and Piper's classifications were adopted to determine the geochemical facies and evaluate the governing geochemical processes.

\section{Study area description}

Study area is located in Nalgonda district between $16.91^{\circ}$ and $17.36^{\circ}$ North latitudes and $78.77^{\circ}$ and $79.59^{\circ}$ East longitudes spreading an area of about $50 \mathrm{~km}^{2}$ (Fig. 1). This area falls under semi-arid category with an annual average rainfall of $674 \mathrm{~mm}$ (CGWB 2013) which is mostly received during south west monsoon (i.e. June to September). The study area comprises of a hard terrain physiography with low to moderately dissected hills and valleys of both structural and denudational origin (Fig. 2). The average elevation is about 480-800 $\mathrm{m}$ above mean sea level (CGWB 2013). The study area has structural and geomorphic lineaments with dykes, joints and fractures (Fig. 2). River Krishna along with the tributaries Musi, Aler, Dindi, Halia and Peddavagu rivers form the drainage for this area which is dendritic to sub-dendritic in nature. The geology of the study area comprises Archaean crystalline rocks of granites, gneisses, schists and intrusive. Formations such as limestones, quartzites and shales are also encountered in the study area. Top zone mostly comprises of weathered formation ranging from 5 to $10 \mathrm{~m}$ while the deeper zones are dominated by fractured granitic rocks (Brindha et al. 2011; CGWB 2013). Most of the water supply to irrigation is met by shallow groundwater, streams or tanks. Wells tapping shallow weathered zone range from 5 to $12 \mathrm{~m}$ below ground level (bgl) while deeper wells tap up to $100 \mathrm{~m}$ bgl (CGWB 2013; Keesari et al. 2014b).

\section{Sample collection and methodology}

Samples from bore well, hand pump and open wells of different depths covering entire study area were collected. A total of 40 samples were collected during pre-monsoon and 38 samples during post-monsoon season of 2012 (Fig. 1). Sampled water was passed through $0.45 \mu \mathrm{m}$ pore size membrane filters and stored in acid-washed polyethylene bottles. For cation measurements, samples were acidified by adding ultrapure nitric acid to $\mathrm{pH} 2$. Physical parameters like temperature, electrical conductivity, $\mathrm{pH}, \mathrm{DO}$ were measured in the field using portable metres (Hanna, Make). Alkalinity was measured in field by titration of $10 \mathrm{ml}$ of water sample with $0.02 \mathrm{~N} \mathrm{H}_{2} \mathrm{SO}_{4}$, the mixed indicator (Bromocresol green-Methyl red) was used for indicating the end point of the titration. Major anions viz., $\mathrm{Cl}^{-}, \mathrm{SO}_{4}{ }^{2-}, \mathrm{NO}_{3}{ }^{-}$and $\mathrm{F}^{-}$and major cations viz., $\mathrm{Na}^{+}, \mathrm{K}^{+}, \mathrm{Mg}^{2+}$ and $\mathrm{Ca}^{2+}$ were analysed using ion chromatography (DX-500) with electrochemical detector (ED 40) in conductivity mode. The accuracy of the analysis was checked using charge balance error, which is calculated for each sample using the equation below. The error was within the allowed limit of $\pm 5 \%$ (Hounslow 1995).

$\% \mathrm{CBE}=\frac{\text { meq }(\text { cations })-\text { meq }(\text { anions })}{\text { meq }(\text { cations })+\text { meq }(\text { anions })} \times 100$

\section{Results and discussion}

\section{General water quality}

A summary of hydrochemical data is given in Table 1 . The seasonal variations of hydrochemical data is represented in the box whiskers plots (Fig. 3a-k). The temperature varies from 28.7 to $36.3{ }^{\circ} \mathrm{C}$, with an average of $30.9^{\circ} \mathrm{C}$, and the $\mathrm{pH}$ values range from 5.52 to 7.6 with an average of 7.17 during pre-monsoon and 7.33-8.77 with an average of 7.9 during post-monsoon season (Table 1). Most of the groundwater samples indicate alkaline nature $(\mathrm{pH}>7)$. The increased $\mathrm{pH}$ in the post-monsoon can be attributed to dissolution of carbonate minerals present in the unsaturated zone. The $\mathrm{pH}$ 


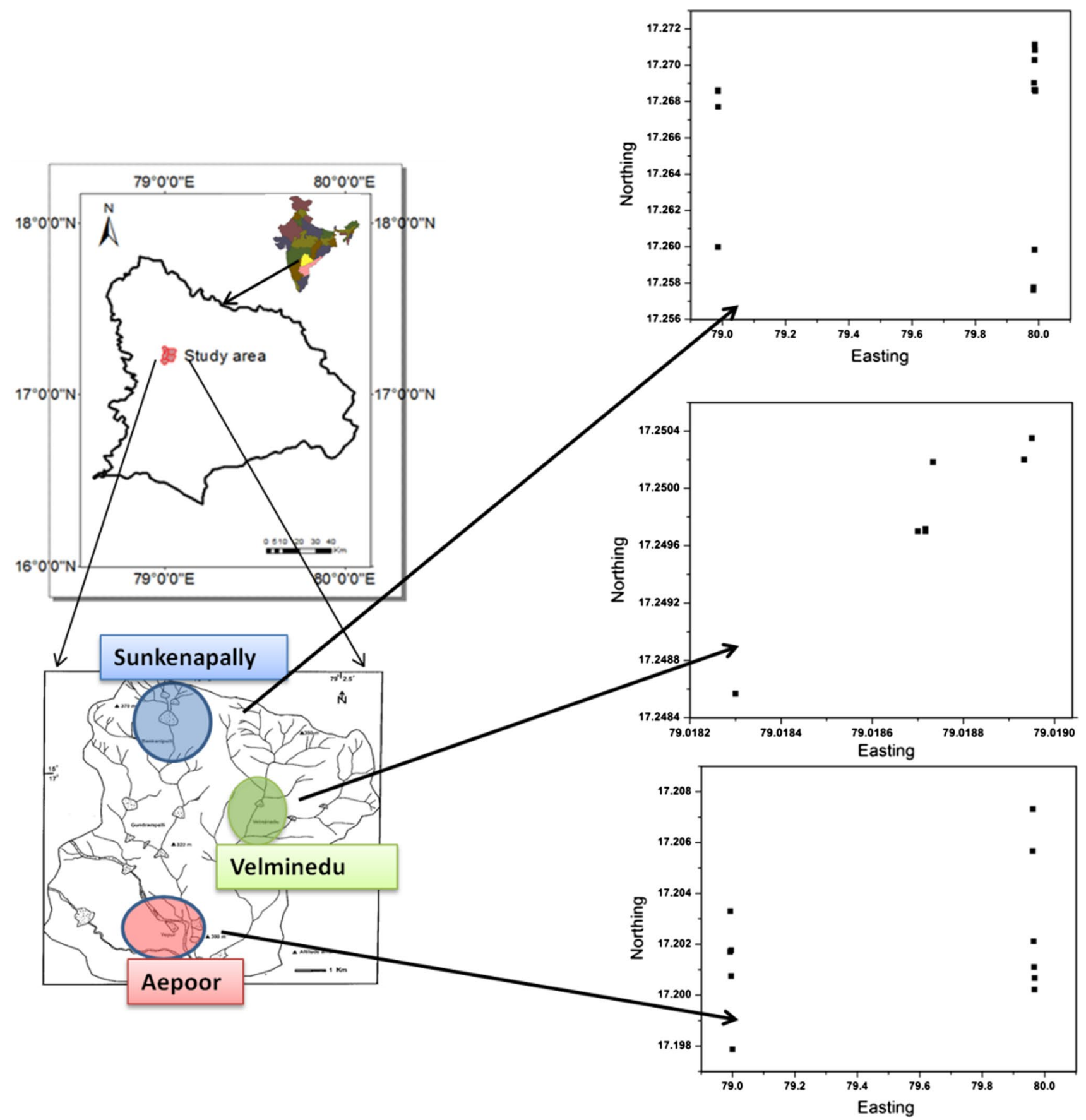

Fig. 1 Sampling location map

value of all the samples are within the permissible limit of 6.5-8.5 prescribed for drinking water by BIS (2012) and WHO (2011) except for few samples given in Table 2. Dissolved ions and salinity is represented by EC and it varies from 499 to $1999 \mu \mathrm{S} / \mathrm{cm}$ with an average of $887 \mu \mathrm{S} / \mathrm{cm}$ in pre-monsoon and from 291 to $1897 \mu \mathrm{S} / \mathrm{cm}$ with an average of $870 \mu \mathrm{S} / \mathrm{cm}$ in post-monsoon season (Table 1). From the bar diagram of variation of EC (Fig. 4), it is clear that in 54\% of the samples show a decrease in EC during pre-monsoon compared to post-monsoon, which could be due to addition of salts to groundwater through unsaturated zone. During the infiltration of rainwater, the salts that are accumulated in unsaturated zone leach into shallow groundwater leading to higher salinity. Total dissolved solid (TDS in $\mathrm{mg} / \mathrm{L}$ ) was calculated from the EC measured by using the formula (Weiner 2013; Sharma et al. 2017):

$\operatorname{TDS}(\mathrm{mg} / \mathrm{L})=0.67 \times \mathrm{EC}(\mu \mathrm{S} / \mathrm{cm})$ 


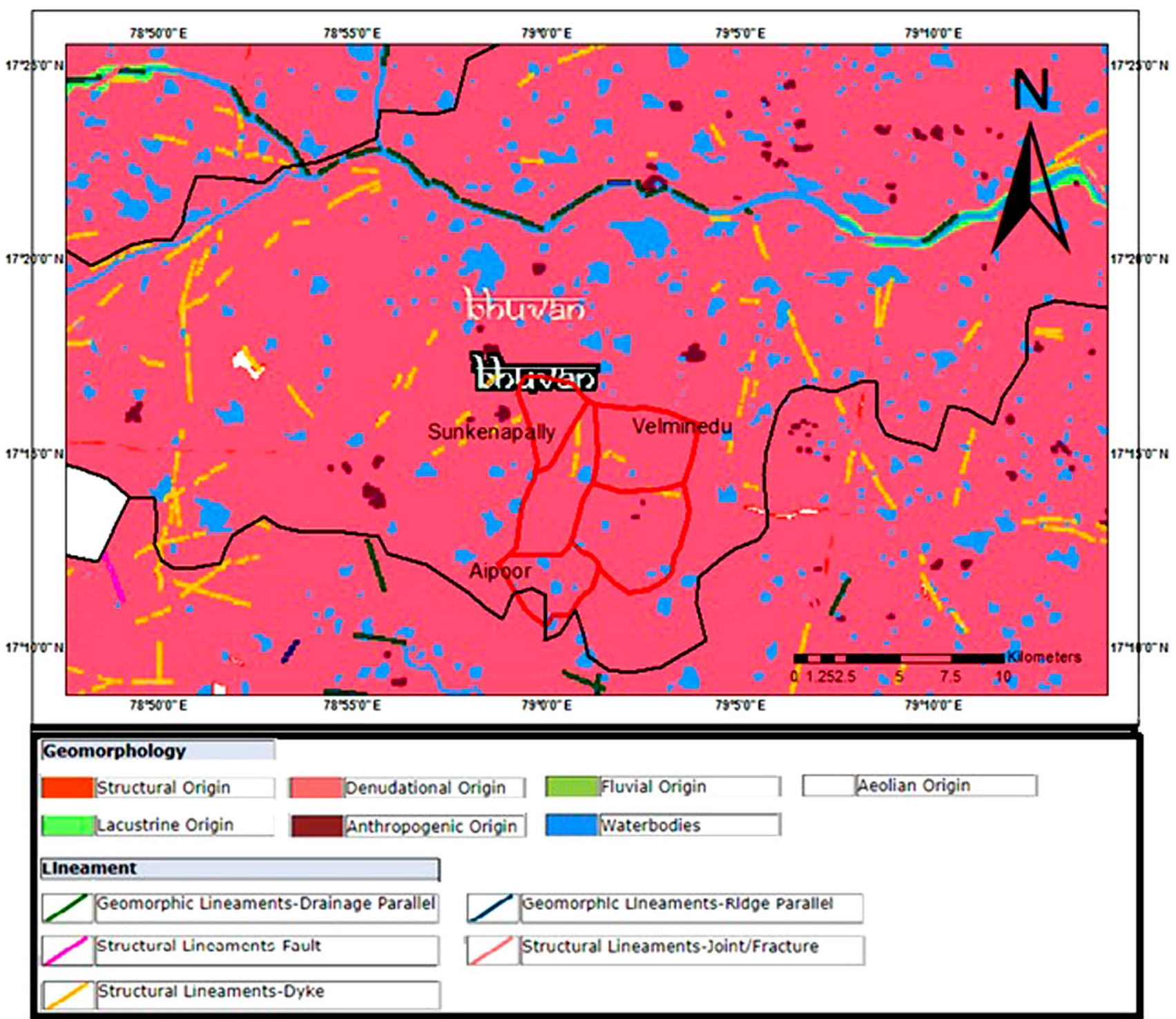

Fig. 2 Geomorphology and Lineament map of the study area (modified after GSI and NRSC 2012)

The TDS values vary from 334 to $1339 \mathrm{mg} / \mathrm{L}$ with an average of $594 \mathrm{mg} / \mathrm{L}$ during pre-monsoon and from 195 to $1271 \mathrm{mg} / \mathrm{L}$ with a mean of $583 \mathrm{mg} / \mathrm{L}$ during post-monsoon (Table 1). TDS is mainly contributed by dissolution of salts present in the unsaturated zone through rainwater percolation (Sharma et al. 2017). DO levels in water are maintained by dissolution of atmospheric oxygen as well as photosynthesis by aquatic plants and it decreases with higher temperature, salinity and elevation. DO values vary from 0.13 to $1.74 \mathrm{mg} / \mathrm{L}$ with a mean of $1.13 \mathrm{mg} / \mathrm{L}$ (Table 1 ).

\section{Suitability for drinking}

Table 2 shows the percentage of samples exceeding the Maximum Permissible Limits (MPL) set by WHO and BIS for each parameters. It is clear from the table that in the premonsoon the dominant contaminant is $\mathrm{F}^{-}$with $30 \%$ samples exceeding the permissible limit of $1.5 \mathrm{mg} / \mathrm{L}$ (Table 2). Other parameters like $\mathrm{NO}_{3}{ }^{-}$, total alkalinity and total hardness are also higher than permissible limits in 27.5, 15 and $27.5 \%$ of samples, respectively (Table 2). $\mathrm{F}^{-}$and $\mathrm{NO}_{3}{ }^{-}$contamination is seen in fewer samples (10 and 26.3\%, respectively) during 
Table 1 Physicochemical parameters for both pre and post-monsoon season

\begin{tabular}{|c|c|c|c|c|c|c|}
\hline Parameter & Season & Minimum & Maximum & Median & Average & SD \\
\hline \multirow[t]{2}{*}{ EC } & Pre & 499 & 1999 & 797.5 & 887.88 & 299.26 \\
\hline & Post & 291 & 1897 & 824.5 & 870 & 431.74 \\
\hline \multirow[t]{2}{*}{$\mathrm{pH}$} & Pre & 5.52 & 7.6 & 7.17 & 7.17 & 0.33 \\
\hline & Post & 7.33 & 8.77 & 7.9 & 7.9 & 0.4 \\
\hline $\mathrm{T}$ & Post & 28.7 & 36.3 & 30.1 & 30.9 & 2.23 \\
\hline DO & Pre & 0.13 & 1.74 & 1.27 & 1.13 & 0.42 \\
\hline \multirow[t]{2}{*}{ TA } & Pre & 0 & 923.8 & 251.7 & 330.7 & 270.3 \\
\hline & Post & 18 & 954.7 & 360.5 & 406.4 & 311.1 \\
\hline \multirow[t]{2}{*}{ TDS } & Pre & 334 & 1339 & 534 & 594 & 200 \\
\hline & Post & 195 & 1271 & 552 & 583 & 289 \\
\hline \multirow[t]{2}{*}{$\mathrm{TH}$} & Pre & 7.5 & 1458 & 231.4 & 404 & 354 \\
\hline & Post & 56.3 & 1621.3 & 416.5 & 584.3 & 417.43 \\
\hline \multirow[t]{2}{*}{$\mathrm{Na}^{+}$} & Pre & 16.2 & 708.9 & 156.7 & 233.0 & 183.5 \\
\hline & Post & 21.7 & 659 & 239.2 & 261.2 & 170.16 \\
\hline \multirow[t]{2}{*}{$\mathrm{K}^{+}$} & Pre & 0.1 & 16.3 & 2.99 & 4.2 & 3.99 \\
\hline & Post & 1.1 & 22.5 & 2.5 & 3.3 & 3.58 \\
\hline \multirow[t]{2}{*}{$\mathrm{Ca}^{2+}$} & Pre & 1 & 336 & 24.95 & 61.7 & 77.54 \\
\hline & Post & 0 & 336 & 81.63 & 104.7 & 92.66 \\
\hline \multirow[t]{2}{*}{$\mathrm{Mg}^{2+}$} & Pre & 0 & 170 & 38.09 & 60.8 & 44.93 \\
\hline & Post & 7.9 & 209 & 68.38 & 78.5 & 52.8 \\
\hline \multirow[t]{2}{*}{$\mathrm{F}^{-}$} & Pre & 0.18 & 3.4 & 0.7 & 1.12 & 0.94 \\
\hline & Post & 0 & 2.6 & 0.5 & 0.72 & 0.62 \\
\hline \multirow[t]{2}{*}{$\mathrm{Cl}^{-}$} & Pre & 10.2 & 529 & 79.48 & 154 & 143.5 \\
\hline & Post & 11 & 740 & 97.83 & 178.9 & 168.32 \\
\hline \multirow[t]{2}{*}{$\mathrm{SO}_{4}{ }^{2-}$} & Pre & 9.5 & 177.8 & 37.5 & 59 & 43.53 \\
\hline & Post & 8.4 & 201 & 44.09 & 62.4 & 51.26 \\
\hline \multirow[t]{2}{*}{$\mathrm{NO}_{3}^{-}$} & Pre & 3.3 & 236 & 34 & 48.9 & 48.69 \\
\hline & Post & 6.4 & 302 & 26.23 & 48.9 & 59.62 \\
\hline \multirow[t]{2}{*}{$\mathrm{HCO}_{3}^{-}$} & Pre & 0 & 1878.4 & 511.88 & 672.6 & 549.63 \\
\hline & Post & 36.6 & 1941.4 & 733.2 & 826.3 & 632.66 \\
\hline
\end{tabular}

TDS, total dissolved solids (mg/L); DO, dissolved oxygen $(\mathrm{mg} / \mathrm{L})$; $\mathrm{T}$, temperature $\left({ }^{\circ} \mathrm{C}\right)$; EC, electrical conductivity $(\mu \mathrm{s} / \mathrm{cm})$; TA, total alkalinity $(\mathrm{mg} / \mathrm{L})$; TH, total hardness $(\mathrm{mg} / \mathrm{L})$; SD standard deviation; $\mathrm{Ca}^{2+}$, calcium $(\mathrm{mg} / \mathrm{L}) ; \mathrm{Mg}^{2+}$, magnesium $(\mathrm{mg} / \mathrm{L}) ; \mathrm{Na}^{+}$, sodium $(\mathrm{mg} / \mathrm{L}) ; \mathrm{K}^{+}$, potassium $(\mathrm{mg} / \mathrm{L}) ; \mathrm{F}^{-}$, fluoride $(\mathrm{mg} / \mathrm{L})$; $\mathrm{HCO}_{3}{ }^{-}$, bicarbonate $(\mathrm{mg} / \mathrm{L}) ; \mathrm{Cl}^{-}$, chloride $(\mathrm{mg} / \mathrm{L}) ; \mathrm{SO}_{4}{ }^{2-}$, sulphate $(\mathrm{mg} / \mathrm{L}) ; \mathrm{NO}_{3}{ }^{-}$, nitrate $(\mathrm{mg} / \mathrm{L})$ post-monsoon, while alkalinity and total hardness increased up to 36.8 and $44.7 \%$, respectively (Table 2; Fig. $3 g$, i, k).

TDS and Total Hardness (TH) are the common indicators of drinking water suitability. As per BIS limits all samples show TDS values within permissible limit in both the seasons but as per WHO guidelines 5\% samples (pre-monsoon) and $10.5 \%$ samples (post-monsoon) are above limits (Table 2). The higher percentages during post-monsoon can be attributed to addition of salts through percolating rainwater. Classification of groundwater based on TDS is shown in Table 3.

Hardness of the water increases due to the increase of alkaline earths such as calcium and magnesium (Narsimha and Sudarshan 2017). The presence of calcite and dolomite minerals are the main reasons for increased $\mathrm{Ca}^{2+}$ and $\mathrm{Mg}^{2+}$ concentrations in groundwater (Adimalla and Venkatayogi 2018; Sharma et al. 2017). High TH in drinking water causes many disease viz. calcifications problem of arteries, urinary calculus, kidney or bladder diseases and stomach problems (Sengupta 2013). TH (mg/L of $\left.\mathrm{CaCO}_{3}\right)$ was determined by the following equation (Todd 1980):

$\mathrm{TH}=2.497 \times \mathrm{Ca}^{2+}+4.115 \times \mathrm{Mg}^{2+}$

where $\mathrm{TH}, \mathrm{Ca}^{2+}, \mathrm{Mg}^{2+}$ concentrations are expressed in $\mathrm{mg} / \mathrm{L}$. TH values vary from 7.5 to $1458 \mathrm{mg} / \mathrm{L}$ with an average of $404 \mathrm{mg} / \mathrm{L}$ during pre-monsoon and 56.3-1621 mg/L with an average of $584 \mathrm{mg} / \mathrm{L}$ (Table 2). Classification of groundwater done by Durfor and Becker (1964) on the basis of $\mathrm{TH}$ is given in Table 3. From the table, it can be seen 

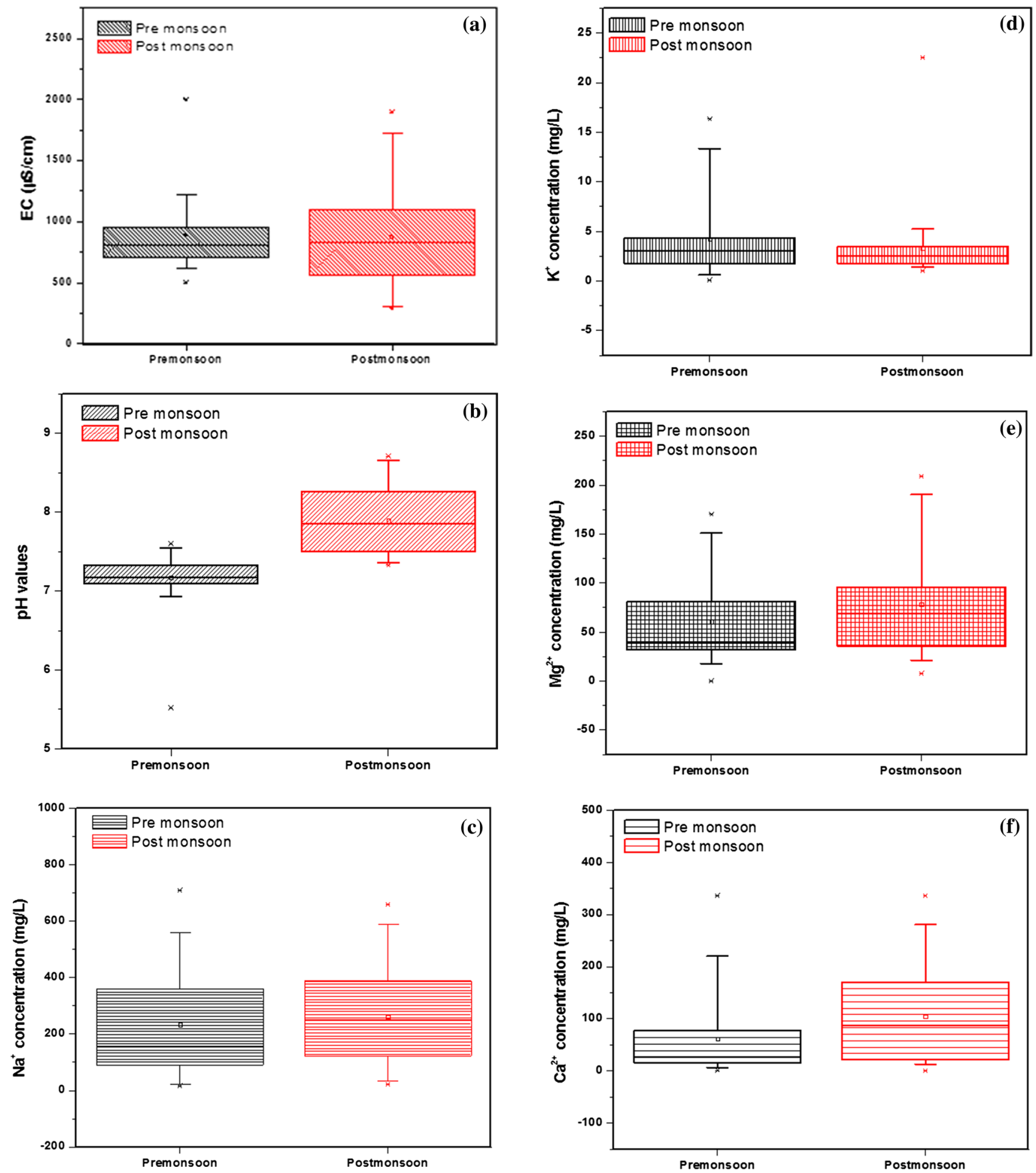

Fig. 3 Box-Whisker Plots showing seasonal variation in a EC $(\mu \mathrm{S} /$ $\mathrm{cm})$; b $\mathrm{pH}$; $\mathbf{c ~ N a} \mathrm{Na}^{+}$concentration $(\mathrm{mg} / \mathrm{L}) ; \mathbf{d ~ K}^{+}$concentration $(\mathrm{mg} / \mathrm{L})$; e $\mathrm{Mg}^{2+}$ concentration $(\mathrm{mg} / \mathrm{L})$; $\mathbf{f ~ C a}^{2+}$ concentration $(\mathrm{mg} / \mathrm{L}) ; \mathbf{g ~ F}^{-}$concentration $(\mathrm{mg} / \mathrm{L}) ; \mathbf{h ~ C l}^{-}$concentration $(\mathrm{mg} / \mathrm{L}) ; \mathbf{i} \mathrm{NO}_{3}{ }^{-}$concentration $(\mathrm{mg} / \mathrm{L}) ; \mathbf{j} \mathrm{SO}_{4}{ }^{2-}$ concentration $(\mathrm{mg} / \mathrm{L}) ; \mathbf{k}$ Alkalinity as $\mathrm{CaCO}_{3}(\mathrm{mg} / \mathrm{L})$

Fig. 3 (continued)

that 67.5 and $84.2 \%$ samples from pre and post-monsoon respectively fall in very hard category.

Sodium $\left(\mathrm{Na}^{+}\right)$in water comes mainly from feldspar like mineral and anthropogenic sources (Kumar et al. 2009). $\mathrm{Na}^{+}$ values vary from 16.2 to $709 \mathrm{mg} / \mathrm{L}$ during pre-monsoon with 

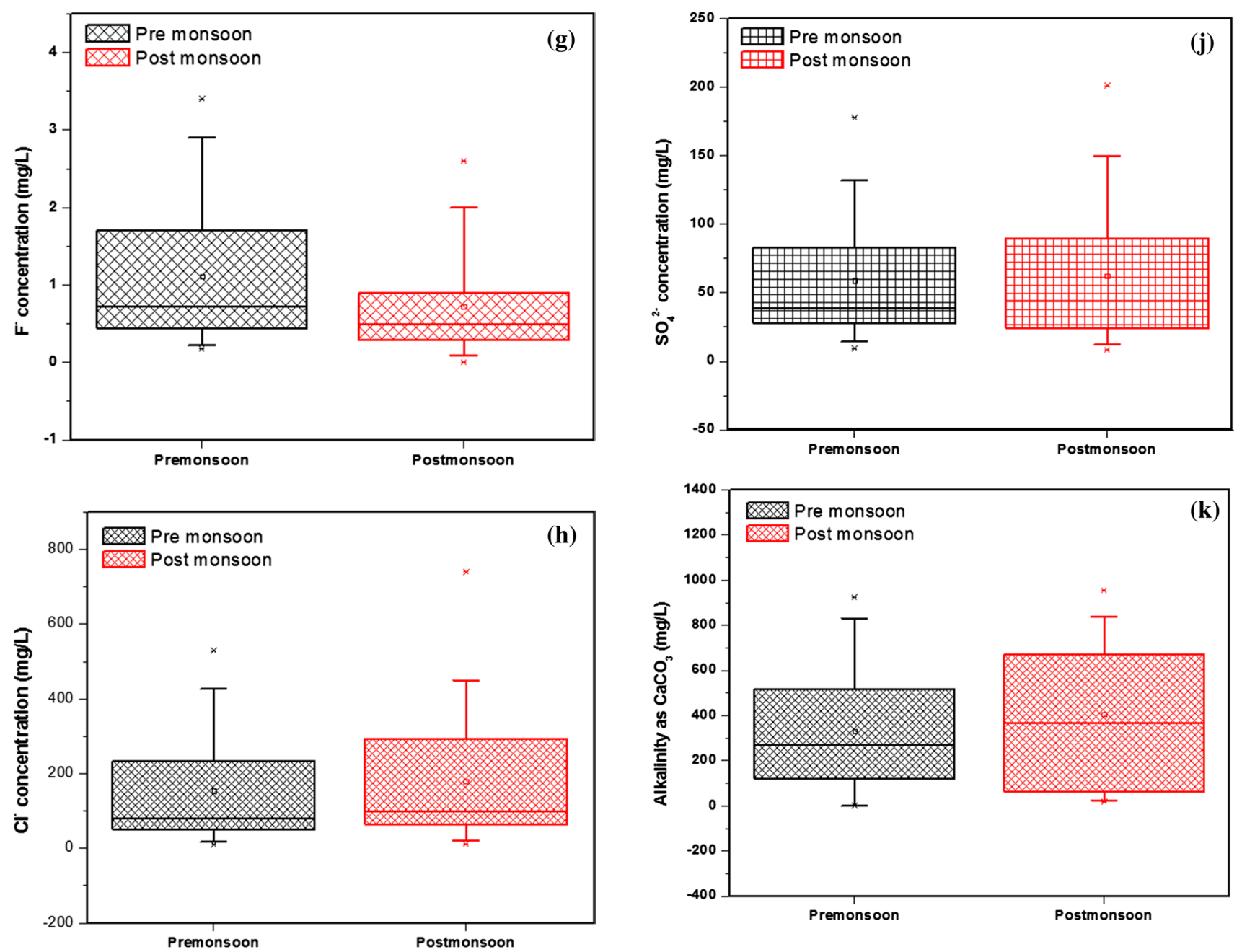

Fig. 3 (continued)

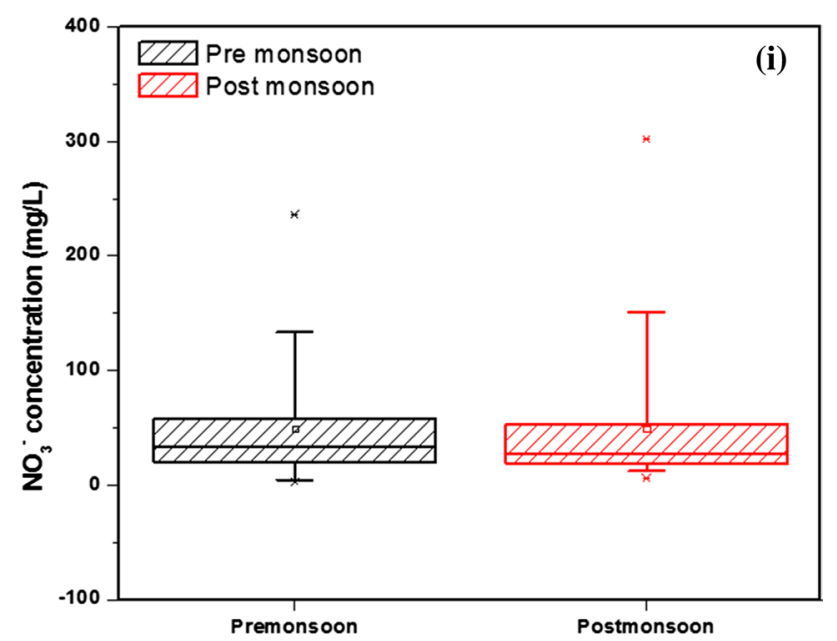

Fig. 3 (continued)

an average value $233 \mathrm{mg} / \mathrm{L}$ and from 21.7 to $659 \mathrm{mg} / \mathrm{L}$ during post-monsoon with an average of $261 \mathrm{mg} / \mathrm{L}$ (Table 1; Fig. 3c). Potash feldspar acts as an anthropogenic source

of $\mathrm{K}^{+}$in water. Orthoclase, microcline and clay minerals are major sources of $\mathrm{K}^{+}$in groundwater, and it may also be derived through ion-exchange process (Hem 1985). $\mathrm{K}^{+}$ concentration varies from 0.1 to $16.3 \mathrm{mg} / \mathrm{L}$ with an average of $4.2 \mathrm{mg} / \mathrm{L}$ for pre-monsoon samples and from 1.1 to $22.5 \mathrm{mg} / \mathrm{L}$ with an average of $3.3 \mathrm{mg} / \mathrm{L}$ during post-monsoon samples (Table 1, Fig. 3d). There are no guidelines prescribed for $\mathrm{Na}^{+}$and $\mathrm{K}^{+}$for drinking water, but for people with heart conditions excess $\mathrm{Na}^{+}$intake can be a matter of concern (WHO 2011) and high $\mathrm{K}^{+}$concentration is harmful for human digestive and nervous system due to its laxative effect (Keesari et al. 2016) (Fig. 3d).

Other important water quality parameters are $\mathrm{Ca}^{2+}$ and $\mathrm{Mg}^{2+}$ which control the $\mathrm{TH}$ of water. The desirable level (DL) of $\mathrm{Ca}^{2+}$ in drinking water is $75 \mathrm{mg} / \mathrm{L}$, and the MPL permissible limit is $200 \mathrm{mg} / \mathrm{L}$ (BIS 2012). Deficiency in $\mathrm{Ca}^{2+}$ results in rickets, while higher levels might cause accumulation in different body parts and kidney problems. The $\mathrm{Ca}^{2+}$ concentration in the samples varies from 1 to $336 \mathrm{mg} / \mathrm{L}$ with a mean value of $61.7 \mathrm{mg} / \mathrm{L}$ in pre-monsoon 
Table 2 Suitability to drinking purpose, comparison of pre- and post-monsoon samples on the basis of BIS and WHO standards

\begin{tabular}{|c|c|c|c|c|c|c|c|c|}
\hline \multirow[t]{2}{*}{ Parameter } & \multicolumn{2}{|c|}{ BIS (2012) } & \multirow[t]{2}{*}{$\begin{array}{l}\text { WHO (2011) } \\
\text { guideline value }\end{array}$} & \multicolumn{2}{|c|}{$\begin{array}{l}\text { Percentage samples having } \\
\text { higher values than BIS (2012) }\end{array}$} & \multicolumn{2}{|c|}{$\begin{array}{l}\text { Percentage samples having } \\
\text { higher values than WHO (2011) }\end{array}$} & \multirow{2}{*}{$\begin{array}{l}\text { Effect on human body when } \\
\text { greater than maximum permis- } \\
\text { sible limit }\end{array}$} \\
\hline & DL & MPL & & Pre-monsoon & Post-monsoon & Pre-monsoon & Post-monsoon & \\
\hline $\mathrm{T}$ & - & - & - & - & - & - & - & $\begin{array}{l}\text { Temperature affects usefulness } \\
\text { of water for different purposes. } \\
\text { Uniformly low temperature } \\
\text { water is usually preferred by } \\
\text { users. With increasing depth } \\
\text { of aquifer the temperature of } \\
\text { groundwater is increased }\end{array}$ \\
\hline $\mathrm{DO}$ & - & - & - & - & - & - & - & $\begin{array}{l}\text { Basic requirement of higher } \\
\text { forms of aquatic life }\end{array}$ \\
\hline $\mathrm{pH}$ & $6.5-8.5$ & No relaxation & $6.5-8.5$ & 0 & 0 & 0 & 0 & $\begin{array}{l}\text { Affects the taste of water and } \\
\text { also mucous membrane }\end{array}$ \\
\hline $\mathrm{TH}$ & 200 & 600 & 500 & 27.5 & 44.7 & 30 & 44.7 & $\begin{array}{l}\text { Causes Calcification at arteries. } \\
\text { Kidney and Stomach problems } \\
\text { also common }\end{array}$ \\
\hline TDS & 500 & 2000 & 1000 & 0 & 0 & 5 & 10.5 & $\begin{array}{c}\text { May cause gastrointestinal irrita- } \\
\text { tion and decreases palatability }\end{array}$ \\
\hline TA & 200 & 600 & - & 15 & 36.8 & - & - & Unpleasant taste \\
\hline $\mathrm{Na}^{+}$ & - & - & - & - & - & - & - & $\begin{array}{l}\text { Large concentration affects } \\
\text { irrigation and industrial use. } \\
\text { Give water salty taste when } \\
\text { combined with chloride. } \\
\text { Harmful for people with heart } \\
\text { conditions }\end{array}$ \\
\hline $\mathrm{K}^{+}$ & - & - & - & - & - & - & - & $\begin{array}{l}\text { High } \mathrm{K}^{+} \text {concentration is } \\
\text { harmful for human digestive } \\
\text { and nervous system due to its } \\
\text { laxative effect }\end{array}$ \\
\hline $\mathrm{Ca}^{2+}$ & 75 & 200 & 300 & 7.5 & 10.5 & 2.5 & 5.3 & $\begin{array}{l}\text { Deficiency causes various type } \\
\text { of rickets and increased level } \\
\text { may cause kidney and blad- } \\
\text { der problems and urination } \\
\text { disorder }\end{array}$ \\
\hline $\mathrm{Mg}^{2+}$ & 30 & 100 & 100 & 20 & 23.7 & 20 & 23.7 & $\begin{array}{l}\text { Salts are cathartic and diuretic } \\
\text { high concentration poses } \\
\text { problems of laxative effect less } \\
\text { amount may affect functions of } \\
\text { enzymes }\end{array}$ \\
\hline $\mathrm{F}^{-}$ & 1 & 1.5 & 1.5 & 30 & 10 & 30 & 10 & $\begin{array}{l}\text { Dental carries may occur above } \\
1.5 \mathrm{mg} / \mathrm{L} \text {, high } \mathrm{F}^{-} \text {results crip- } \\
\text { pling skeletal fluorosis }\end{array}$ \\
\hline $\mathrm{NO}_{3}^{-}$ & 45 & No relaxation & 50 & 27.5 & 26.3 & 27.5 & 26.3 & Methemoglobinemia in infants \\
\hline $\mathrm{SO}_{4}{ }^{2-}$ & 200 & 400 & 250 & 0 & 0 & 0 & 0 & Causes gastrointestinal irritation \\
\hline $\mathrm{Cl}^{-}$ & 250 & 1000 & 250 & 0 & 0 & 25 & 31.6 & $\begin{array}{l}\text { Injurious to heart and kidney } \\
\text { patients other than this taste, } \\
\text { palatability and digestion is } \\
\text { effected }\end{array}$ \\
\hline $\mathrm{HCO}_{3}^{-}$ & - & - & - & - & - & - & - & $\begin{array}{l}\text { Combined with calcium and } \\
\text { magnesium forms carbonate } \\
\text { hardness }\end{array}$ \\
\hline
\end{tabular}

DO, dissolved oxygen $(\mathrm{mg} / \mathrm{L})$; T, temperature $\left({ }^{\circ} \mathrm{C}\right)$; TDS, total dissolved solids $(\mathrm{mg} / \mathrm{L})$; TA, total alkalinity as $\mathrm{CaCO} 3(\mathrm{mg} / \mathrm{L})$; $\mathrm{TH}$, total hardness as $\mathrm{CaCO}_{3}(\mathrm{mg} / \mathrm{L}) ; \mathrm{Ca}^{2+}$, calcium $(\mathrm{mg} / \mathrm{L}) ; \mathrm{Mg}^{2+}$, magnesium $(\mathrm{mg} / \mathrm{L}) ; \mathrm{Na}^{+}$, sodium $(\mathrm{mg} / \mathrm{L}) ; \mathrm{K}^{+}$, potassium $(\mathrm{mg} / \mathrm{L}) ; \mathrm{F}^{-}$, fluoride $(\mathrm{mg} / \mathrm{L}) ; \mathrm{Cl}^{-}$, chloride $(\mathrm{mg} / \mathrm{L}) ; \mathrm{SO}_{4}{ }^{2-}$, sulphate $(\mathrm{mg} / \mathrm{L}) ; \mathrm{NO}_{3}{ }^{-}$, nitrate $(\mathrm{mg} / \mathrm{L}) ; \mathrm{HCO}_{3}{ }^{-}$, bicarbonate $(\mathrm{mg} / \mathrm{L})$

and from 0 to $336 \mathrm{mg} / \mathrm{L}$ with a mean value of $104.7 \mathrm{mg} / \mathrm{L}$ in post- monsoon (Table 1 ; Fig. $3 f$ ). $\mathrm{Mg}^{2+}$ is an essential activator for enzymes and various biochemical reactions in body but excess $\mathrm{Mg}^{2+}$ is cathartic and diuretic (WHO 2009). $\mathrm{Mg}^{2+}$ values range from 0 to $170 \mathrm{mg} / \mathrm{L}$ with a mean value
$60.8 \mathrm{mg} / \mathrm{L}$ during pre-monsoon and from 7.9 to $209 \mathrm{mg} / \mathrm{L}$ with a mean $78.5 \mathrm{mg} / \mathrm{L}$ during post-monsoon (Table 1, Fig. 3e).

Bicarbonate concentration $\left(\mathrm{HCO}_{3}{ }^{-}\right)$in groundwater of the study area ranges from 0 to $1878.4 \mathrm{mg} / \mathrm{L}$ 


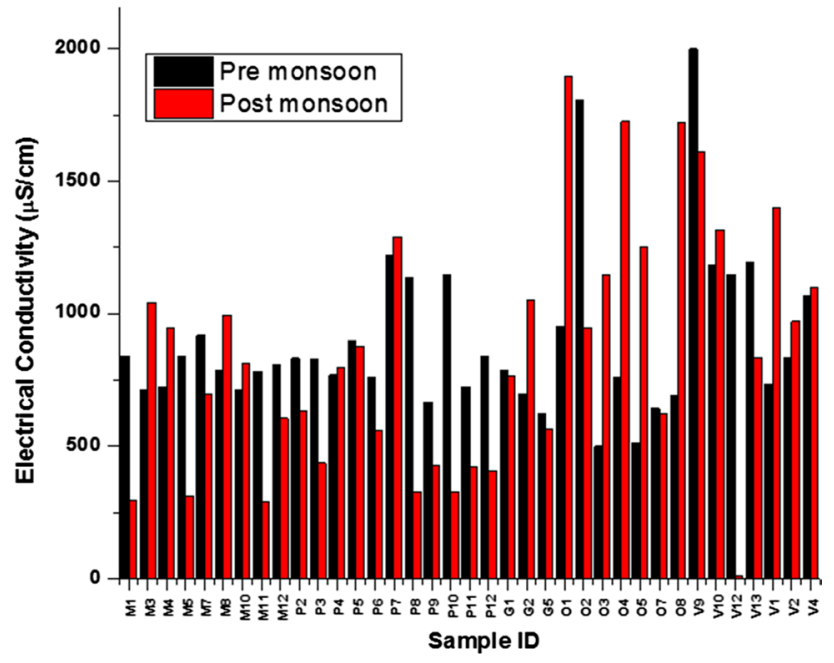

Fig. 4 Seasonal variations in electrical conductivity of water samples $(\mu \mathrm{S} / \mathrm{cm})$

during pre-monsoon with an average of 673 and 36.6 to $1941 \mathrm{mg} / \mathrm{L}$ with an average of $826 \mathrm{mg} / \mathrm{L}$ during postmonsoon (Table 1). The higher alkalinity due to higher bicarbonate ion concentration can be attributed to silicate weathering and carbonate mineral dissolution in the presence of soil $\mathrm{CO}_{2}(\mathrm{~g})$ releasing $\mathrm{HCO}_{3}{ }^{-}$in the groundwater (Hem 1985, 1986; Narsimha and Sudarshan 2017). During pre-monsoon $\mathrm{Cl}^{-}$concentration in the area varies from 10.2 to $529 \mathrm{mg} / \mathrm{L}$ with an average of $154 \mathrm{mg} / \mathrm{L}$ and from 11 to $740 \mathrm{mg} / \mathrm{L}$ with an average of $178.9 \mathrm{mg} / \mathrm{L}$ during post-monsoon (Table 1; Fig. 3h). Natural and anthropogenic, both act as the sources of $\mathrm{Cl}^{-}$in groundwater. High concentration of chloride in water causes health problems in human like hypertension, ventricular hypertrophy, osteoporosis, renal stones and asthma (McCarthy 2004; Raviprakash and Krishna 1989). $\mathrm{SO}_{4}{ }^{2-}$ amount in the area ranges from 9.5 to $178 \mathrm{mg} / \mathrm{L}$ with mean value $59 \mathrm{mg} / \mathrm{L}$ in pre-monsoon and from 8.4 to $201 \mathrm{mg} / \mathrm{L}$ with an average value of $62.4 \mathrm{mg} / \mathrm{L}$ during post-monsoon (Table 1; Fig. $3 \mathrm{j})$. The presence of gypsum $\left(\mathrm{CaSO}_{4} \cdot 2 \mathrm{H}_{2} \mathrm{O}\right)$, anhydrite $\left(\mathrm{CaSO}_{4}\right)$ and oxidation of sulphide minerals are the main reasons of higher concentration of $\mathrm{SO}_{4}{ }^{2-}$ in groundwater (Han et al. 2016). The anthropogenic sources of $\mathrm{SO}_{4}{ }^{2-}$ in the region are fertilisers, industrial effluents etc. (Lakshmi et al. 2016). Excess $\mathrm{SO}_{4}{ }^{2-}$ with $\mathrm{Mg}^{2+}$ or $\mathrm{Na}^{+}$ causes gastrointestinal problem in the consumers (WHO 1997).

A major portion of the study area shows contamination by $\mathrm{NO}_{3}{ }^{-}$and $\mathrm{F}^{-}$(Table 2). $\mathrm{NO}_{3}{ }^{-}$concentration in the area varies between 3.3 and $236 \mathrm{mg} / \mathrm{L}$ with an average of $48.9 \mathrm{mg} / \mathrm{L}$ in pre-monsoon and between 6.4 and $302 \mathrm{mg} / \mathrm{L}$ with an average of $48.9 \mathrm{mg} / \mathrm{L}$ (Table 1; Fig. 3i). Nitrate in groundwater is derived mainly from poultry farms, animal wastages and septic tank leakages, agricultural activities, and decaying of organic domestic wastes (Jalali 2005; Lee et al. 2003; Narsimha and Sudarshan 2017). High $\mathrm{NO}_{3}{ }^{-}$in drinking water causes methemoglobinemia (blue baby syndrome) in infants (WHO 1997). $\mathrm{F}^{-}$Concentration in the area varies between 0.18 and $3.4 \mathrm{mg} / \mathrm{L}$ with an average of $1.12 \mathrm{mg} / \mathrm{L}$ for pre-monsoon samples and between 0 and $2.6 \mathrm{mg} / \mathrm{L}$ with an average of $0.72 \mathrm{mg} / \mathrm{L}$ for post-monsoon samples (Table 1; Fig. 3g). Granites/ gneisses are the major rock types in this study area which have the highest fluoride containing minerals viz. fluorite $(0-3.3 \%)$, biotite $(0.1-1.7 \%)$, and hornblende $(0.1-1.1 \%)$. So, the major reason for elevated level of fluoride concentration in the groundwater in this region could be due to water rock interaction and weathering of $\mathrm{F}^{-}$rich minerals. Anthropogenic activities such as, application of fertilisers and industrial activities like brick kilning also add to fluoride levels in the aquifers (Brindha and Elango 2011; Datta et al. 1996; Hem 1986; Pickering 1985). Consumption of fluoride rich water causes dental fluorosis (Heller et al. 1997; Viswanathan et al. 2009) and aids weakening
Table 3 Groundwater classification on the basis of TDS and TH

\begin{tabular}{llll}
\hline $\begin{array}{l}\text { Values of parameters } \\
\text { Class of water }\end{array}$ & $\begin{array}{l}\text { \% of samples in pre- } \\
\text { monsoon }\end{array}$ & $\begin{array}{l}\text { \% samples } \\
\text { in post-mon- } \\
\text { soon }\end{array}$ \\
\hline $\begin{array}{l}\text { TDS }(\mathrm{mg} / \mathrm{L}) \\
500\end{array}$ & Desirable for drinking & 35 & 39.5 \\
$500-1000$ & Permissible for drinking & 60 & 50 \\
$1000-3000$ & Useful for irrigation & 5 & 10.5 \\
$>3000$ & Unfit for drinking and irrigation & 0 & 0 \\
$\mathrm{TH}\left(\mathrm{mg} \mathrm{CaCO}_{3} / \mathrm{L}\right)$ & & & \\
$<60$ & Soft & 2.5 & 2.6 \\
$60-120$ & Moderately hard & 7.5 & 2.6 \\
$121-181$ & Hard & 22.5 & 10.52 \\
$>181$ & Very hard & 67.5 & 84.2 \\
\hline
\end{tabular}


of bones and skeletal fluorosis (National Research Council 1993).

\section{Water Quality Index (WQI)}

In order to provide overall the quality of groundwater for drinking purpose, WQI was estimated. All the measured parameters in this study were considered for estimating the WQI and the weighted arithmetic index method suggested by Brown et al. (1970) was used for WQI calculation. The equation used for the calculation is:

$q_{n}=100\left[V_{n}-V_{i 0}\right] /\left[S_{n}-V_{i 0}\right]$

where $n$ is defined as the number of water quality parameters and $q_{n}$ refers to the quality rating of the $n$th parameter which reflects the relative contribution towards the polluted water with respect to the standard value.

$q_{n}=$ Quality rating for the $n$th parameter of water quality $V_{n}=$ Measured value of $n$th parameter for a particular sample

$S_{n}=$ Standardised permissible value of $n$th parameter $V_{i 0}=$ Ideal value of $n$th parameter in pure water (i.e. 0 for all parameters except $\mathrm{pH}$ which has neutral value of 7)

WQI is calculated using this equation:

$\mathrm{WQI}=\frac{\Sigma q_{n} W_{n}}{\Sigma W_{n}}$

where $W_{n}=$ unit weight of $n$th parameters, which is calculated by:

$W_{n}=\mathrm{K} / S_{n}$

$\mathrm{K}=$ Constant of proportionality and calculated as:

$\mathrm{K}=\frac{1}{\Sigma\left(\frac{1}{S_{n}}\right)}$

Table 4 Relative weight of chemical parameters for WQI Index

\begin{tabular}{ll}
\hline Parameters & Relative weight $\left(\mathrm{W}_{\mathrm{i}}\right)$ \\
\hline $\mathrm{EC}$ & 0.000802 \\
$\mathrm{pH}$ & 0.141576 \\
$\mathrm{TDS}$ & 0.001203 \\
$\mathrm{TH}$ & 0.002407 \\
$\mathrm{TA}$ & 0.002006 \\
$\mathrm{Ca}^{2+}$ & 0.004011 \\
$\mathrm{Mg}^{2+}$ & 0.012034 \\
$\mathrm{~F}^{-}$ & 0.802265 \\
$\mathrm{NO}_{3}{ }^{-}$ & 0.024068 \\
$\mathrm{SO}_{4}{ }^{2-}$ & 0.004814 \\
$\mathrm{Cl}^{-}$ & 0.004814 \\
$\Sigma \mathrm{W}_{\mathrm{i}}=$ & 1.000000
\end{tabular}

Table 5 Water Quality Index (WQI) for pre- and postmonsoon

\begin{tabular}{|c|c|c|c|}
\hline \multicolumn{2}{|c|}{ Sample } & \multicolumn{2}{|l|}{ WQI } \\
\hline Pre & Post & Pre & Post \\
\hline M1 & M1 & 19.9 & 90.1 \\
\hline M3 & M3 & 37.5 & 47.8 \\
\hline M4 & M4 & 46.6 & 50.1 \\
\hline M5 & M5 & 47.2 & 61.5 \\
\hline M7 & M7 & 27.7 & 88.8 \\
\hline M8 & M8 & 175.5 & 52.6 \\
\hline M10 & M10 & 88.1 & 144.4 \\
\hline M11 & M11 & 34.8 & 42.7 \\
\hline M12 & M12 & 25.7 & 33.5 \\
\hline & $\mathrm{P} 1$ & & 18.4 \\
\hline $\mathrm{P} 2$ & $\mathrm{P} 2$ & 15.6 & 9.5 \\
\hline P3 & $\mathrm{P} 3$ & 20.6 & 27.6 \\
\hline $\mathrm{P} 4$ & $\mathrm{P} 4$ & 18.2 & 27.6 \\
\hline P5 & P5 & 143.9 & 30.0 \\
\hline P6 & P6 & 45.1 & 25.5 \\
\hline P7 & P7 & 31.2 & 35.3 \\
\hline P8 & P8 & 38.7 & 53.0 \\
\hline P9 & P9 & 47.1 & 20.7 \\
\hline $\mathrm{P} 10$ & P10 & 18.6 & 26.4 \\
\hline P11 & P11 & 15.1 & 39.3 \\
\hline P12 & $\mathrm{P} 12$ & 34.0 & 33.5 \\
\hline G1 & G1 & 127.7 & 20.1 \\
\hline G2 & $\mathrm{G} 2$ & 86.2 & 69.2 \\
\hline G3 & & 128.9 & \\
\hline G4 & & 102.9 & \\
\hline G5 & G5 & 17.7 & 39.5 \\
\hline $\mathrm{O} 1$ & $\mathrm{O} 1$ & 102.2 & 120.9 \\
\hline $\mathrm{O} 2$ & $\mathrm{O} 2$ & 59.4 & 114.8 \\
\hline $\mathrm{O} 3$ & $\mathrm{O} 3$ & 37.7 & 31.9 \\
\hline O4 & $\mathrm{O} 4$ & 31.4 & 49.3 \\
\hline $\mathrm{O} 5$ & O5 & 13.3 & 32.2 \\
\hline $\mathrm{O} 7$ & $\mathrm{O} 7$ & 62.9 & 118.7 \\
\hline $\mathrm{O} 8$ & $\mathrm{O} 8$ & 190.3 & 59.0 \\
\hline V9 & V9 & 123.6 & 146.7 \\
\hline V10 & V10 & 131.9 & 63.0 \\
\hline V11 & & 159.1 & \\
\hline V12 & V12 & 85.2 & 13.8 \\
\hline V13 & V13 & 121.4 & 93.2 \\
\hline V1 & V 1 & 50.7 & 44.8 \\
\hline V2 & $\mathrm{v} 2$ & 37.3 & 19.8 \\
\hline V4 & v 4 & 20.6 & 12.1 \\
\hline
\end{tabular}

Table 4 lists the relative weights of chemical parameters for WQI calculation. The calculated WQI for each sample is given in Table 5 and description of the classification of water on the basis of WQI is given in Table 6. According to the WQI values $27.5 \%$ of samples in pre-monsoon and $13.2 \%$ of samples in post-monsoon are unsuitable for drinking. 
Table 6 Classification of groundwater on the basis of Water Quality Index (WQI)

\begin{tabular}{llll}
\hline WQI & $\begin{array}{l}\text { Classification of pre- and post-monsoon } \\
\text { samples based on WQI }\end{array}$ & $\begin{array}{l}\text { Percentage of pre-mon- } \\
\text { soon samples }\end{array}$ & $\begin{array}{l}\text { Percentage of post- } \\
\text { monsoon samples }\end{array}$ \\
\hline $0-25$ & Excellent water quality & 22.5 & 18.4 \\
$26-50$ & Good water quality & 35 & 42.1 \\
$51-75$ & Poor water quality & 7.5 & 18.4 \\
$76-100$ & Very poor water quality & 7.5 & 7.9 \\
$>100$ & Unsuitable for drinking & 27.5 & 13.2 \\
\hline
\end{tabular}

Good-to-excellent quality is found in $57.5 \%$ of samples during pre-monsoon and $60.5 \%$ in post-monsoon.

\section{Irrigation suitability}

In addition to different irrigation suitability indicators (SAR, EC, Na \%, RSC, PI, MR, RSBC, SH, PS, SSP and MR), Doneen's chart, Wilcox and USSL diagrams were also used to assess the groundwater suitability for irrigational use in this area. Groundwater classification based on EC values (Richards 1954) and the percentage of samples falling in each class is given in Table 7. 35\% samples in pre-monsoon and 39.5\% samples in post-monsoon fall in the good category and the rest in permissible category. The groundwater samples were also classified as per salinity hazard (SH) (Richards 1954). Table 7 shows that 35 and $39.5 \%$ of the samples fall in good category during pre- and post-monsoon seasons, respectively. None of the samples fall in the excellent or unsuitable categories.

Soluble sodium percentage (SSP) is an important parameter to assess the sodium hazard towards irrigation. It is defined by Todd (1960) as shown below:

$\mathrm{SSP}=\frac{\mathrm{Na}^{+}}{\mathrm{Ca}^{2+}+\mathrm{Mg}^{2+}+\mathrm{K}^{+}} \times 100$

where all the concentrations are in meq/L. Table 7 enlists the classification of the samples on the basis of SSP values. Table 7 shows that $77.5 \%$ of the pre-monsoon samples fall in the doubtful to unsuitable category, while $82 \%$ of the samples fall in the doubtful to unsuitable category during post-monsoon.

High sodium ion concentration in water causes low permeability of soil and hence infiltration of water becomes difficult. The presence of calcium and magnesium in soil allows easy cultivation and makes soil more permeable. The increase in sodium in soil replaces calcium and magnesium from soil and soil becomes hard and compact leading to reduced infiltration and poor internal drainage (Karanth 1987). The SAR values are calculated using the following equation (Richards 1954):

$\mathrm{SAR}=\frac{\mathrm{Na}^{+}}{\sqrt{\frac{\mathrm{Ca}^{2+}+\mathrm{Mg}^{2+}}{2}}}$ where the concentrations are expressed in meq/L. The SAR values vary from 0.6 to 25.8 during pre-monsoon and from 0.5 to 14.8 during post-monsoon, $82.5 \%$ of the pre-monsoon samples fall in the excellent category and only one sample in doubtful category. During post-monsoon, $94.7 \%$ samples fall in the excellent category (Table 7). High sodium concentration also leads to alkaline soils by combining with $\mathrm{CO}_{3}{ }^{2-}$ and $\mathrm{HCO}_{3}{ }^{-}$and saline soils by combining with $\mathrm{Cl}^{-}$. Both alkaline and saline soils are unfavourable for irrigation. Sodium hazard is expressed as percentage sodium $(\mathrm{Na} \%$, Wilcox 1948). The following equation is used to calculate the $\mathrm{Na} \%$ parameter (Wilcox 1955):

$\mathrm{Na} \%=\frac{\left(\mathrm{Na}^{+}+\mathrm{K}^{+}\right) \times 100}{\mathrm{Na}^{+}+\mathrm{K}^{+}+\mathrm{Ca}^{2+}+\mathrm{Mg}^{2+}}$

All units are in milliequivalents per litre. $\mathrm{Na} \%$ values for the pre-monsoon samples varied from 18.2 to 91.5 , while in post-monsoon season, it ranged from 12.1 to 84.9. Values suggest that a majority of samples from both the seasons fall in excellent-to-permissible zones, while $32.5 \%$ samples in pre-monsoon and $26.3 \%$ of samples in post-monsoon fall in doubtful to unsafe category (Table 7). High $\mathrm{Na}^{+}$and EC reduce the osmotic pressure in the plants limiting the intake of nutrients present in water for proper growth (Keesari et al. 2016). To study the integrated effect of $\mathrm{EC}$ and $\mathrm{Na} \%$, Wilcox diagram is used (Wilcox 1955). From the diagram (Fig. 5), it can be observed that groundwater is more suitable for irrigation during post-monsoon season because $76.3 \%$ samples fall in excellent-to-good and good-to-permissible categories in comparison to $67.5 \%$ samples during pre-monsoon. The quality of groundwater in pre-monsoon season is degraded mainly because of high amount of $\mathrm{Na}^{+}, \mathrm{HCO}_{3}{ }^{-}$and TDS due to extreme evaporative conditions.

The United States Salinity Laboratory diagram was used to describe the irrigation suitability of groundwater of this region in a detailed way (USSL 1954). Based on the USSL classification, the study area is classified into major five zones, C2S1, C2S2, C3S1, C3S2 and C3S3 (Fig. 6). Samples falling in the $\mathrm{C} 2 \mathrm{~S} 1$ and $\mathrm{C} 2 \mathrm{~S} 2$ region are good for irrigation while samples falling in $\mathrm{C} 3 \mathrm{~S} 1$ and $\mathrm{C} 3 \mathrm{~S} 2$ region are marginally suitable for irrigation because of high salinity hazard values. Samples falling in the $\mathrm{C} 3 \mathrm{~S} 3$ regionare unsuitable 
Table 7 Irrigational suitability of groundwater

\begin{tabular}{|c|c|c|c|c|}
\hline Parameters & References & Classification based on parameters & $\begin{array}{l}\% \text { of samples } \\
\text { from pre-mon- } \\
\text { soon }\end{array}$ & $\begin{array}{l}\% \text { of samples } \\
\text { from post-mon- } \\
\text { soon }\end{array}$ \\
\hline $\mathrm{EC}(\mu \mathrm{s} / \mathrm{cm})$ & Richards (1954) & & & \\
\hline$<250$ & & Excellent & 0 & 0 \\
\hline $250-750$ & & Good & 35 & 39.5 \\
\hline $750-2000$ & & Permissible & 65 & 60.5 \\
\hline $2000-3000$ & & Doubtful & 0 & 0 \\
\hline$>3000$ & & Unsuitable & 0 & 0 \\
\hline Alkalinity hazard (SAR) & Richards (1954) & & & \\
\hline$<10$ & & Excellent & 82.5 & 94.7 \\
\hline $10-18$ & & Good & 15 & 5.3 \\
\hline $18-26$ & & Doubtful & 2.5 & 0 \\
\hline$>26$ & & Unsuitable & 0 & 0 \\
\hline Per cent sodium ( $\mathrm{Na} \%)$ & Wilcox (1955) & & & \\
\hline$>20$ & & Excellent & 2.5 & 2.6 \\
\hline $20-40$ & & Good & 20 & 18.4 \\
\hline $40-60$ & & Permissible & 45 & 52.6 \\
\hline $60-80$ & & Doubtful & 15 & 23.7 \\
\hline$>80$ & & Unsafe & 17.5 & 2.6 \\
\hline Residual sodium carbonate (RSC) & Eaton (1950) & & & \\
\hline$<1.25$ & & Good & 42.5 & 50 \\
\hline $1.25-2.5$ & & Doubtful & 10 & 7.9 \\
\hline$>2.5$ & & Unsuitable & 47.5 & 42.1 \\
\hline Salinity hazard $(\mathrm{SH})(\mathrm{EC}$ values in $\mu \mathrm{s} / \mathrm{cm})$ & Richards (1954) & & & \\
\hline $100-250$ & & Excellent & 0 & 0.0 \\
\hline $250-750$ & & Good & 35 & 39.5 \\
\hline $750-2250$ & & Doubtful & 65 & 60.5 \\
\hline$>2250$ & & Unsuitable & 0 & 0.0 \\
\hline Residual sodium bicarbonate (RSBC) & Gupta (1983) & & & \\
\hline$<5$ & & Satisfactory & 42.5 & 39.5 \\
\hline $5-10$ & & Marginal & 30 & 18.4 \\
\hline$>10$ & & Unsatisfactory & 27.5 & 42.1 \\
\hline Potential salinity (PS) & Doneen (1962) & & & \\
\hline$<5$ & & Excellent to Good & 62.5 & 55.3 \\
\hline $5-10$ & & Good to Injurious & 20 & 28.9 \\
\hline$>10$ & & Injurious to satisfactory & 17.5 & 15.8 \\
\hline Soluble sodium percentage (SSP) & Todd (1960) & & & \\
\hline $0-20$ & & Excellent & 0 & 2.6 \\
\hline $20-40$ & & Good & 12.5 & 7.9 \\
\hline $40-60$ & & Permissible & 10 & 7.9 \\
\hline $60-80$ & & Doubtful & 12.5 & 15.8 \\
\hline$>80$ & & Unsuitable & 65 & 65.8 \\
\hline Magnesium ratio (MR) & Raghunath (1987) & & & \\
\hline$<50$ & & Suitable & 12.5 & 36.8 \\
\hline$>50$ & & Unsuitable & 87.5 & 63.2 \\
\hline Kelley ratio (KR) & Kelley (1963) & & & \\
\hline$<1$ & & Suitable & 42.5 & 52.6 \\
\hline $1-2$ & & Marginally suitable & 30 & 34.2 \\
\hline$>2$ & & Unsuitable & 27.5 & 13.2 \\
\hline
\end{tabular}




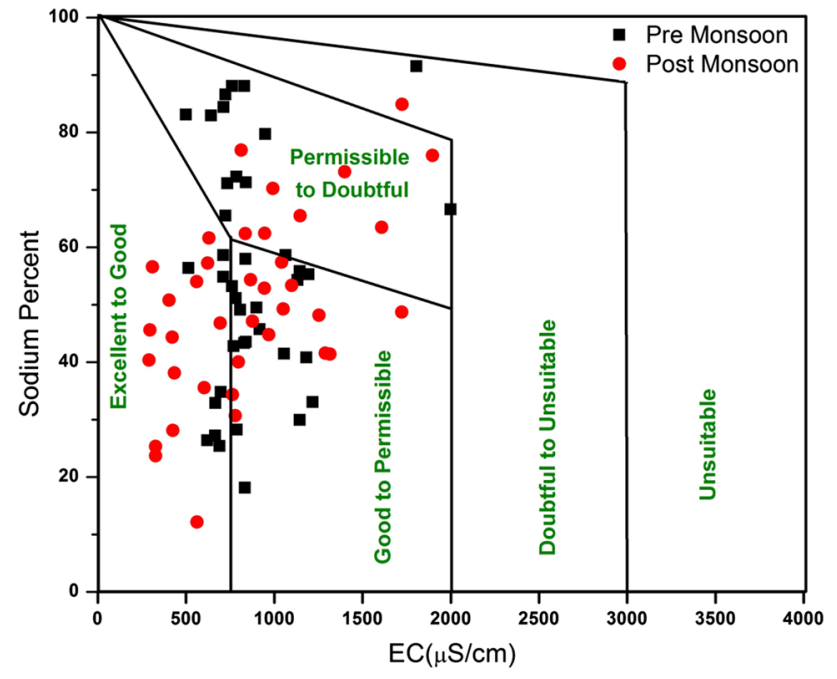

Fig. 5 Wilcox diagram of groundwater samples of the study area for two seasons

for irrigation because of high salinity hazard and high SAR values. The $\mathrm{SH}$ values indicate that $65 \%$ of the pre- and $60.5 \%$ of the post-monsoon samples belong to high salinity zone. The SAR values indicate $82.5 \%$ of the pre- and $95 \%$ of the post-monsoon samples belong to the low SAR (Fig. 6). Overall, $10 \%$ of the pre- and $5.3 \%$ of the post-monsoon samples were found to be unsuitable for irrigation (Fig. 6).

RSC is also an important parameter for assessing the groundwater suitability for irrigation, it is defined as (Eaton 1950):

$\mathrm{RSC}=\left(\mathrm{HCO}_{3}^{-}+\mathrm{CO}_{3}^{2-}\right)-\left(\mathrm{Ca}^{2+}+\mathrm{Mg}^{2+}\right)$

where all the concentrations are in $\mathrm{meq} / \mathrm{L}$.

RSC $<1.25$ indicate suitability of water for irrigation while $1.25-2.5$ is in doubtful category and greater than 2.5 is not useful for irrigation (Lloyd and Heathcote 1985). During premonsoon RSC values in this area range from -12.22 to 15.79 and during post-monsoon, it varies from -7.3 to $13.9 .52 .5 \%$ of samples during pre-monsoon and 58\% during post-monsoon fall under good-to-doubtful category, while rest fall in unsuitable category (Table 7).

Similar to RSC, RSBC is another factor determining the quality of water on the basis of bicarbonate ion concentration. RSBC is defined as (Gupta 1983):

$\mathrm{RSBC}=\mathrm{HCO}_{3}^{-}-\mathrm{Ca}^{2+}$

where all the concentrations are in meq/L. From the summary of Table 7 , it can be seen that $60 \%$ of sample in postmonsoon samples show marginal to unsatisfactory values, while $58 \%$ of samples during pre-monsoon have marginal to unsatisfactory values.

Potential salinity (PS) is defined as the chloride concentration plus half of the sulphate concentration (Doneen 1962);

$\mathrm{PS}=\mathrm{Cl}^{-}+\frac{1}{2} \mathrm{SO}_{4}^{2-}$

Fig. 6 USSL diagram of groundwater samples of the study area for two seasons
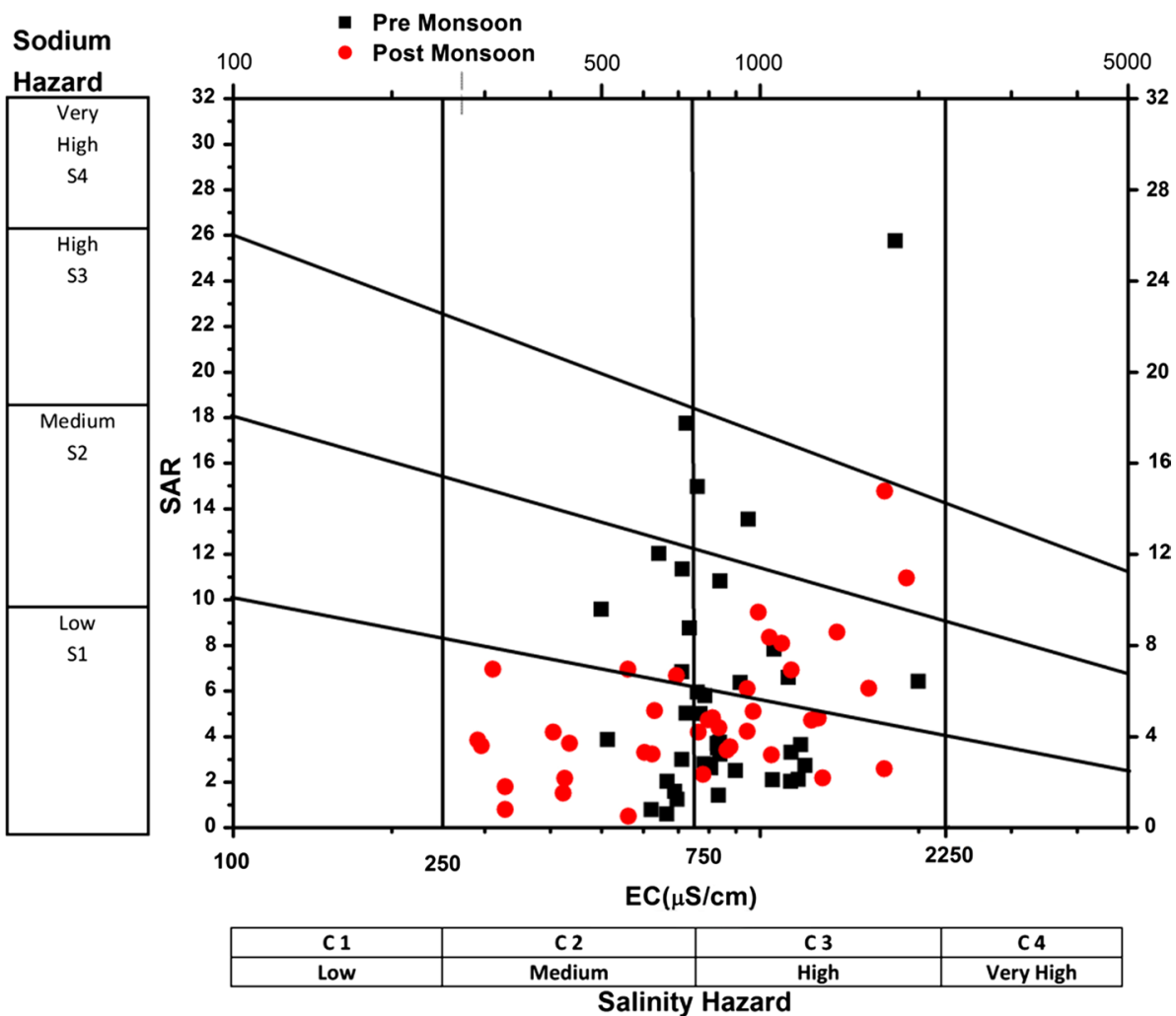

Salinity Hazard 
where all the concentrations are in meq/L. Table 7 shows that $82.5 \%$ of the pre-monsoon and $84.2 \%$ of the post-monsoon samples fall in excellent-to-good and good-to-injurious categories, while rest of the samples (17.5\% during pre- and $15.8 \%$ during post-monsoon season, respectively) falls under injurious to satisfactory category.

Excess magnesium in waters affects the soil quality by increasing the alkalinity and it subsequently decreases the crop yield. The hazard posed by excess $\mathrm{Mg}^{2+}$ in groundwater is indicated by magnesium ratio (MR) defined as (Raghunath 1987):

$\mathrm{MR}=\frac{\mathrm{Mg}^{2+}}{\mathrm{Ca}^{2+}+\mathrm{Mg}^{2+}} \times 100$

All the concentrations are expressed in meq/L. Table 7 shows that $87.5 \%$ of the pre-monsoon samples belong to the unsuitable category while $63 \%$ of the post-monsoon samples fall in this category.

Kelly's ratio (KR) was also estimated to evaluate the groundwater quality for irrigation purposes (Kelley 1963). It is defined as:

$\mathrm{KR}=\frac{\mathrm{Na}^{+}}{\mathrm{Ca}^{2+}+\mathrm{Mg}^{2+}}$

where all the concentrations are in meq/L. KR $>2$ indicates an excess level of sodium in waters and not suitable for irrigation. From Table 7, it can be seen that $72.5 \%$ of the preand $87 \%$ of the post-monsoon samples belong to suitable to marginally suitable category. The rest of the samples belong to the unsuitable category.

Long-term use of groundwater for irrigation purposes affect the permeability index(PI) of groundwater, which in turn is influenced by $\mathrm{Na}^{+}, \mathrm{Ca}^{2+}, \mathrm{Mg}^{2+}$ and $\mathrm{HCO}_{3}{ }^{-}$concentrations. PI is defined by:

$\mathrm{PI}=\frac{\mathrm{Na}^{+}+\sqrt{\mathrm{HCO}_{3}^{-}}}{\mathrm{Ca}^{2+}+\mathrm{Mg}^{2+}+\mathrm{Na}^{+}} \times 100$

where all concentrations are expressed in meq/L. Doneen (1964) has classified water into three groups based on the PI values (Fig. 7). Class I category is considered to be $100 \%$ of maximum permeability and have good prospect for irrigation, class II considers $75 \%$ of maximum permeability and considered to be marginally suitable for irrigation, while class III is associated with $25 \%$ maximum permeability and is unsuitable for irrigation. From the Doneen's chart, it is clear that post-monsoon groundwater is better for irrigation with only one sample in class III unsuitable for irrigation whereas five samples from pre-monsoon fall in class III (Fig. 7).

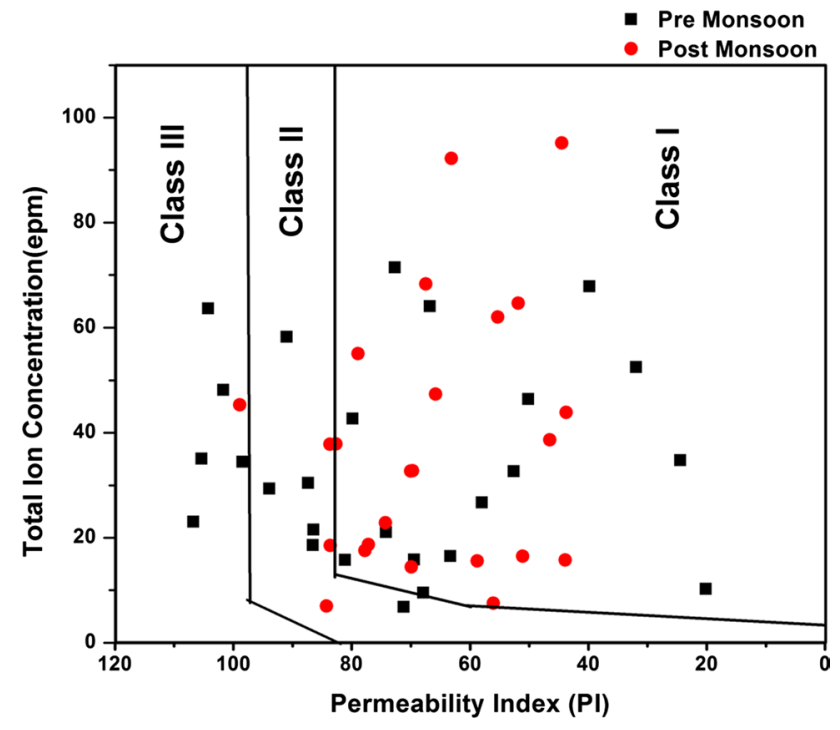

Fig. 7 Doneen's chart for groundwater samples of study area for two seasons

From the evaluation of the groundwater quality with respect to drinking and irrigation purposes, it can be seen that the quality of post-monsoon samples is better than the pre-monsoon samples. The higher levels of $\mathrm{F}^{-}$and $\mathrm{NO}_{3}{ }^{-}$in groundwater are the major concern of this region. However, this study infers that the post-monsoon samples have reduced level of contaminants and also are better for drinking water and irrigation purposes. Hence, increasing the groundwater level through rainwater harvesting can be a viable option to mitigate the water quality problems of this region to a greater extent. Better rainwater harvesting can be achieved through construction of artificial structures and also by desilting the natural tanks available in this region.

\section{Geochemical study of groundwater samples}

Chemical data of major ions are plotted in piper tri-linear diagram (Piper 1944) (Fig. 8a, b) to determine the types of groundwater as well as the geochemical characteristics of the groundwater in the study area. The diagram consists of two triangular fields for cation and anion separately and a diamond shaped field. The diamond field is divided into six major groups representing a characteristic water type. These water groups are (1) $\mathrm{CaHCO}_{3}$, (2) $\mathrm{NaCl}$, (3) mixed $\mathrm{CaNaHCO}_{3}$, (4) mixed $\mathrm{CaMgCl}$, (5) $\mathrm{CaMgClSO}_{4}$ and (6) $\mathrm{NaHCO}_{3}$ type. Piper diagram shows that $\mathrm{Na}^{+}$and $\mathrm{HCO}_{3}{ }^{-}$are the dominant species in both the seasons. The major water types of the study area are found to be: $\mathrm{Na}-\mathrm{Mg}-\mathrm{HCO}_{3}, \mathrm{Na}-\mathrm{Mg}-\mathrm{HCO}_{3}-\mathrm{Cl}, \mathrm{Na}-\mathrm{HCO}_{3}$, $\mathrm{Mg}-\mathrm{Na}-\mathrm{HCO}_{3}, \mathrm{Mg}-\mathrm{Ca}-\mathrm{HCO}_{3}$ and $\mathrm{Na}-\mathrm{Cl}$ (Fig. 8a, b). The comparative analysis of the number of samples falling in each of these groups in the diamond field suggests 
Fig. 8 a Piper diagram of the groundwater samples collected in pre-monsoon 2012. b Piper diagram of the groundwater samples collected in post-monsoon 2012

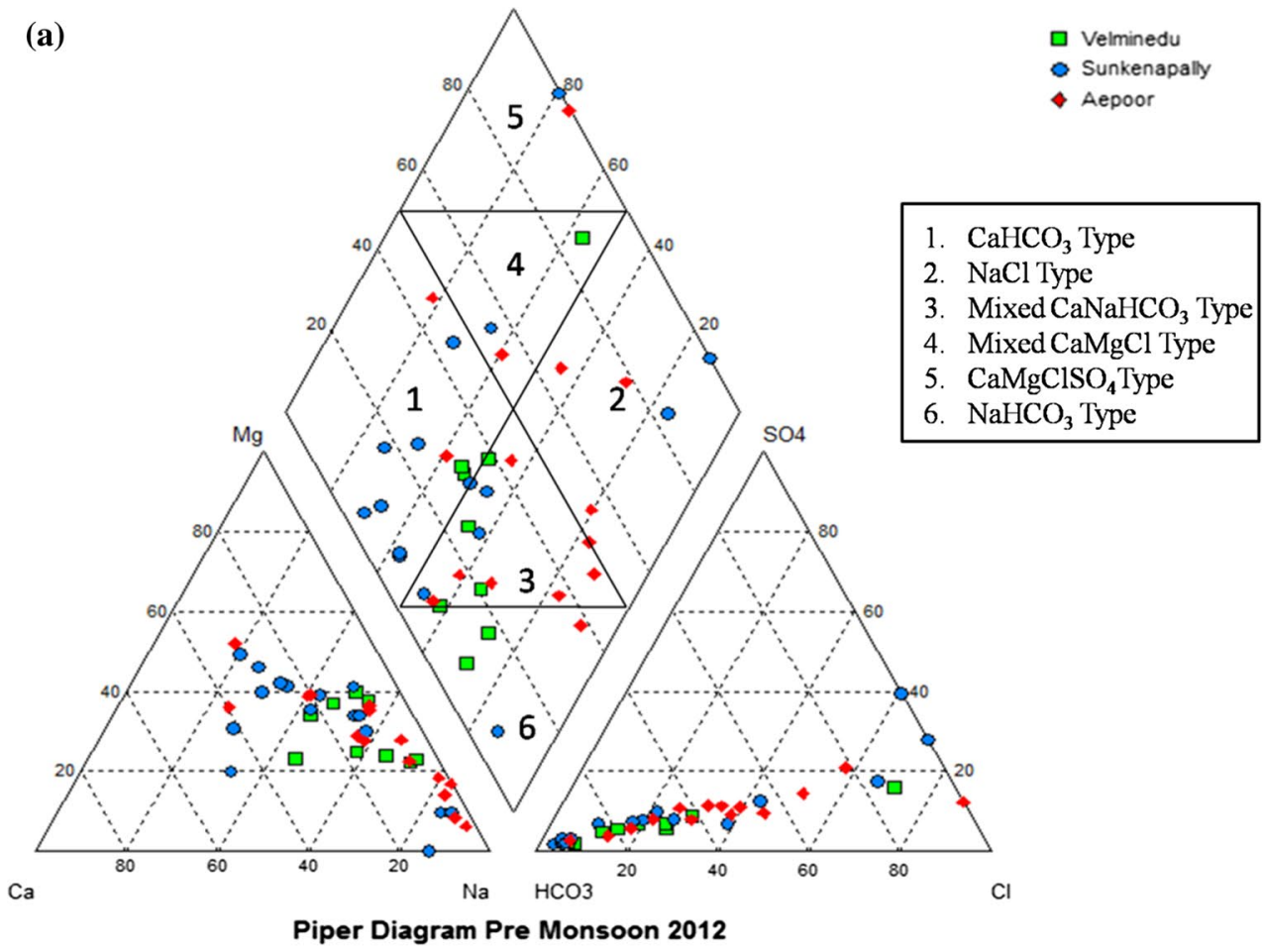

(b)

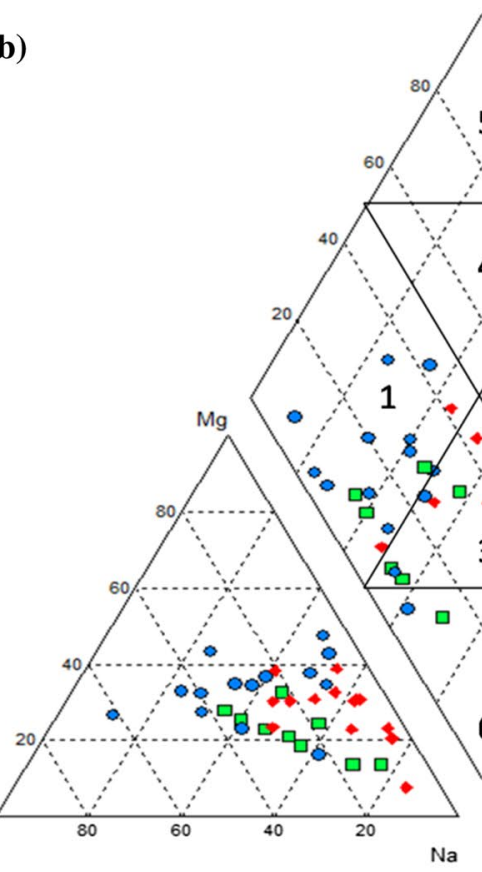

Piper Diagram Post Monsoon 2012
1. $\mathrm{CaHCO}_{3}$ Type

2. NaCl Type

3. Mixed $\mathrm{CaNaHCO}_{3}$ Type

4. Mixed $\mathrm{CaMgCl}$ Type

5. $\mathrm{CaMgClSO}_{4}$ Type

$\mathrm{NaHCO}_{3}$ Type that $40 \%$ samples in the pre-monsoon fall in the group 1 and 2 while $63 \%$ of samples fall in these groups during post-monsoon. This confirms the influence of the rainwater recharge and subsequent dissolution of the salts in the unsaturated zone during post-monsoon season.
Geochemical characteristics of the groundwater are also evaluated by Chadha's plot (Chadha 1999). In order to construct this plot, all the data were transferred to milliequivalent percentages and the difference between $\mathrm{Ca}^{2+}+\mathrm{Mg}^{2+}$ and $\mathrm{Na}^{+}+\mathrm{K}^{+}$for cations, and between $\mathrm{HCO}_{3}{ }^{-}+\mathrm{CO}_{3}{ }^{2-}$ and 


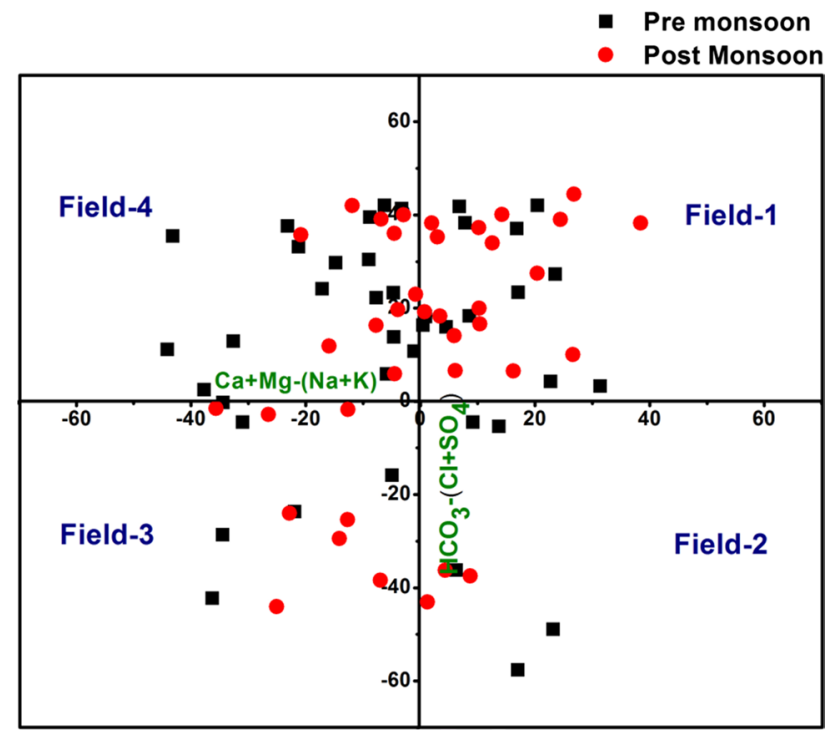

Fig. 9 Geochemical classification based on Chadha's diagram

$\mathrm{Cl}^{-}+\mathrm{SO}_{4}{ }^{2-}$ for anions was calculated. This each quadrant of the plot infers a different hydrochemical process, e.g. Field-1 represents recharging waters $\left(\mathrm{Ca}-\mathrm{HCO}_{3}\right.$ type $)$, Field-2 represents reverse ion-exchange waters $(\mathrm{Ca}-\mathrm{Mg}-\mathrm{Cl}$ type), Field 3 represents end member waters (seawater $\mathrm{Na}-\mathrm{Cl}$ type) and Field 4 represents base ion-exchange waters $\left(\mathrm{Na}-\mathrm{HCO}_{3}\right.$ type). Majority of samples fall in the fields 1 and 4 for both of the seasons, but the relative proportion indicates that more number of post-monsoon samples fall in the field 1 as compared to pre-monsoon. This again corroborates the finding from Piper's diagram that the post-monsoon samples are originated from precipitation, while pre-monsoon samples show base exchange reaction as the governing reaction as indicated below (Hounslow 1995; Keesari et al. 2016) (Fig. 9):

$$
\mathrm{Na}_{2}-\mathrm{Clay}+\mathrm{Ca}^{2+} \rightarrow \mathrm{Ca}^{2+}-\mathrm{Clay}+2 \mathrm{Na}^{+}
$$

A few samples fall in field 3 indicating $\mathrm{Na}-\mathrm{Cl}$ type water. Dissolution of the salts deposited in the unsaturated zone by rainwater can result in $\mathrm{Na}-\mathrm{Cl}$ type water. These samples are also characterised by relatively high EC $(1897 \mu \mathrm{S} / \mathrm{cm})$.

\section{Conclusion}

A current update on the status of groundwater quality and the geochemical characters of the hard rock aquifers of central parts of Telangana State, India, is presented. Suitability of the groundwater for domestic and irrigation purposes was evaluated from the measured hydrochemical parameters in accordance with guideline values prescribed by WHO (2011) and BIS (2012). The overall water quality is assessed using WQI, which indicates that more number of samples have better quality during post-monsoon compared to premonsoon. $\mathrm{F}^{-}$and $\mathrm{NO}_{3}{ }^{-}$were found to be the main inorganic contaminants in groundwater, while high $\mathrm{HCO}_{3}{ }^{-}$concentration renders the water quality poor by increasing the total hardness. Seasonal variation of the hydrochemical data clearly suggests that dissolution of salts in the unsaturated zone by infiltrating rainwater adds to major ions into the groundwater, while $\mathrm{F}^{-}$and $\mathrm{NO}_{3}{ }^{-}$show a reduction in concentration due to rainwater dilution. All the indicators and diagrams depicting the irrigation suitability suggest that post-monsoon samples are more suitable for irrigation than pre-monsoon samples. The geochemical characteristics of groundwater determined by Piper's diagram and Chadha's plot show that post-monsoon groundwater has significant contribution from rain and the chemistry is governed by salt dissolution in unsaturated zone. During pre-monsoon, water rock interaction and ion-exchange processes were found to be more dominating. The study area (Nalgonda District) being a known fluoride contaminated region, implementing rainwater harvesting by constructing suitable artificial structures and desilting the natural tanks available in this area can help increase the groundwater availability and also limit the fluorosis incidences among local population.

Open Access This article is distributed under the terms of the Creative Commons Attribution 4.0 International License (http://creativeco mmons.org/licenses/by/4.0/), which permits unrestricted use, distribution, and reproduction in any medium, provided you give appropriate credit to the original author(s) and the source, provide a link to the Creative Commons license, and indicate if changes were made.

\section{References}

Adimalla N, Venkatayogi S (2018) Geochemical characterization and evaluation of groundwater suitability for domestic and agricultural utility in semi-arid region of Basara, Telangana State, South India. Appl Water Sci 8:44

BIS (2012) Indian standards specification for drinking water. IS:10500:2012, 2nd Rev, BIS, New Delhi

Brindha K, Elango L (2011) Fluoride in groundwater: causes, implications and mitigation measures. In: Monroy SD (ed) Fluoride properties. Applications and environmental management, pp 111-136

Brindha K, Rajesh R, Murugan R, Elango L (2011) Fluoride contamination in groundwater in parts of Nalgonda District, Andhra Pradesh, India. Environ Monit Assess 172(1-4):481-492

Brown RM, McClelland NI, Deininger RA, Tozer RG (1970) Water quality index-do we dare? Water Sew Works 117(10):339-343

Central Ground Water Board (CGWB) (2013) Ground water brochure Nalgonda district, Andhra Pradesh

Chadha DK (1999) A proposed new diagram for geochemical classification of natural waters and interpretation of chemical data. Hydrogeol J 7(5):431-439

Das AK, Prakash P, Kumar G, Ramudu N (2017) RS and GIS based integrated study on hydrogeomorphic unit wise ground water quality evaluation for Nalgonda district, Telangana state. J Geomat 11(1) 
Datta PS, Deb DL, Tyagi SK (1996) Stable isotope $\left({ }^{18} \mathrm{O}\right)$ investigations on the processes controlling fluoride contamination of groundwater. J Contam Hydrol 24(1):85-96

Doneen LD (1962) The influence of crop and soil on percolating water. In: Proceedings 11961 biennial conference on groundwater recharge, pp 156-163

Doneen LD (1964) Notes on water quality in agriculture. Published as a Water Science and Engineering, Paper 4001, Department of Water Sciences and Engineering, University of California

Durfor CN, Becker E (1964) Public water supplies of the 100 largest cities in the United States. Water supply paper no. 1812, pp 343-346

Eaton EM (1950) Significance of carbonate in irrigation water. Soil Sci 69:123-133

GSI and NRSC (2012) National geomorphological and Lineament mapping on 1:50,000 scale. Natural Resources Census Project, National Remote Sensing Centre, ISRO, Hyderabad

Gupta IC (1983) Concept of residual sodium carbonate in irrigation waters in relation to sodic hazard in irrigated soils. Curr Agric 7(3/4):97-113

Han D, Song X, Currell MJ (2016) Identification of anthropogenic and natural inputs of sulfate into a karstic coastal groundwater system in northeast China: evidence from major ions, $\delta^{13} \mathrm{C}_{\mathrm{DIC}}$ and $\delta^{34} \mathrm{~S}_{\mathrm{SO} 4}$. Hydrol Earth Syst Sci 20:1983-1999

Heller KE, Eklund SA, Burt BA (1997) Dental caries and dental fluorosis at varying water fluoride concentrations. J Public Health Dent 57(3): 136-143

Hem JD (1985) Study and interpretation of the chemical characteristics of natural water. USGS Water Supply Paper 2254:117-120

Hem JD (1986) Study and interpretation of the chemical characteristics of natural water, 3rd edn. USGS Water Supply Paper, p 2254

Hounslow AW (1995) Water quality data analysis and interpretation. CRC Press, Boca Raton

Jalali M (2005) Nitrate leaching from agricultural land in Hamadan, western Iran. Agric Ecosyst Environ 110:210-218

Karanth KR (1987) Groundwater assessment, development and management. Tata-McGraw-Hill, New Delhi

Keesari T, Kulkarni UP, Deodhar A, Ramanjaneyulu PS, Sanjukta AK, Kumar US (2014a) Geochemical characterization of ground- water from an arid region in India. Environ Earth Sci 71(11):4869-4888

Keesari T, Mohokar HV, Sahoo BK, Mallesh G (2014b) Assessment of environmental radioactive elements in groundwater in parts of Nalgonda district, Andhra Pradesh, South India using scintillation detection methods. J Radioanal Nucl Chem (JRNC) 302(3):13911398. https://doi.org/10.1007/s10967-014-3566-3

Keesari T, Ramakumar KL, Chidambaram S, Pethperumal S (2016) Understanding the hydrochemical behaviour of groundwater and its suitability for drinking and agricultural purposes in Pondicherry area, South India - a step towards sustainable development. Groundwater Sustain Dev 2-3:143-153

Kelley WP (1963) Use of saline irrigation. WaterSoil Sci 95(4):355-391

Kota N, Kumar SR, Ravi S, Chary SN, Girija P (2016) Fluoride contamination assessment in ground water: case study from Chityala Mandal, Nalgonda District, Telangana. Int J Innov Res Sci Eng Technol 5(6):10047-10053. https://doi.org/10.15680/IJIRS ET.2015.0506072

Kumar SK, Rammohan V, Sahayam JD, Jeevanandam M (2009) Assessment of groundwater quality and hydrogeochemistry of Manimuktha River basin, Tamil Nadu, India. Environ Monit Assess 159:341. https://doi.org/10.1007/s10661-008-0633-7

Lakshmi P, Reddy MS, Reddy CP, Rao AN (2016) Studies of physico-chemical parameters to evaluate quality of water at different zones of Nalagonda District of Telangana, India. J Earth Sci Clim Change 7:4. https://doi.org/10.4172/2157-7617.1000347
Lee SM, Min KD, Woo NC, Kim YJ, Ahn CH (2003) Statistical assessment of nitrate contamination in urban groundwater using GIS. Environ Geol 44:210-221

Lloyd JW, Heathcote JA (1985) Natural inorganic hydrochemistry in relation to groundwater. Clarendon, Oxford, p 294

McCarthy MF (2004) Should we restrict chloride rather than sodium? Med Hypotheses 63:138-148

Narsimha A, Sudarshan V (2017) Contamination of fluoride in groundwater and its effect on human health: a case study in hard rock aquifers of Siddipet, Telangana State, India. Appl Water Sci 7:2501-2512. https://doi.org/10.1007/s13201-016-0441-0

National Research Council (1993) Health effects of ingested fluoride. National Academy Press, Washington, DC

Pickering WF (1985) The mobility of soluble fluoride in soils. Environ Pollut Ser B Chem Phys 9(4):281-308

Piper AM (1944) A graphical procedure in the geochemical interpretation of water analysis. Trans Am Geophys Union 25:914-928

Raghunath HM (1987) Groundwater, 2nd edn. Wiley Eastern Ltd, New Delhi, 563p

Ramesh K, Elango L (2012) Groundwater quality and its suitability for domestic and agricultural use in Tondiar river basin, Tamil Nadu, India. Environ Monit Assess 184(6):3887-3899. https:// doi.org/10.1007/s10661-011-2231-3

Raviprakash S, Krishna RG (1989) The chemistry of ground water in Pravada area with regard to their suitability for domestic and irrigation purpose. Indian J Geochem 4(1):39-54

Richards LA (1954) Diagnosis and improvement of saline and alkali soils. US Department of Agriculture, Agri. Hand book 60, Washington, DC

Scanlon BR, Keese KE, Flint AL, Flint LE, Gaye CB, Edmunds WM, Simmers I (2006) Global synthesis of groundwater recharge in semiarid and arid regions. Hydrol Process 20:3335-3370. https ://doi.org/10.1002/hyp.6335

Sengupta P (2013) Potential health impacts of hard water. Int J Prev Med 4(8):866-875

Sharma DA, Rishi MS, Keesari T (2017) Evaluation of groundwater quality and suitability for irrigation and drinking purposes in southwest Punjab, India using hydrochemical approach. Appl Water Sci 7(6):3137-3150. https://doi.org/10.1007/s 1320 1-016-0456-6

Todd DK (1960) Salt water intrusion of coastal aquifers in the United States. Int Assoc Sci Hydrol (Gentbrugge Belgium) Pub 52:452-461

Todd DK (1980) Ground water hydrology. Wiley, New York

Unnisa SA, Bi SZ (2017) Groundwater quality characterization around Jawaharnagar open dumpsite, Telangana State. Appl Water Sci 7:3911-3918

USSL (1954) Diagnosis and improvement of saline and alkaline soils. United States Salinity Laboratory, US Department of Agriculture, Washington, DC

Vasanthavigar M, Srinivasamoorthy K, Vijayaragavan K, Ganthi RR, Chidambaram S, Anandhan P, Manivannan R, Vasudevan $S$ (2010) Application of water quality index for groundwater quality assessment: Thirumanimuttar sub-basin, Tamilnadu, India. Environ Monit Assess 171(1-4):595-609

Vasu D, Singh SK, Tiwary P, Sahu N, Ray SK, Butte P, Duraisami VP (2017) Influence of geochemical processes on hydrochemistry and irrigation suitability of groundwater in part of semi-arid Deccan Plateau, India. Appl Water Sci 7:3803-3815

Venkateshwarlu M, Reddy MN (2017) A case study on assessment of groundwater quality parameters in and around Lambapur area, Nalgonda District, Telangana state. Int J Civ Eng Technol (IJCIET) 8(7):563-566

Venkateshwarlu M, Rasheed MA, Reddy UVB, Kumar AK (2014) Assessment of groundwater quality in and around Miryalaguda

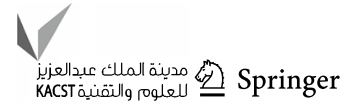


area, Nalgonda district of Andhra Pradesh. Int J Plant Animal Environ Sci 4(2):259-266

Viswanathan G, Jaswanth A, Gopalakrishnan S, Sivailango S (2009) Mapping of fluoride endemic areas and assessment of fluoride exposure. Sci Total Environ 407:1579-1587

Weiner ER (2013) Applications of environmental aquatic chemistry: a practical guide, 3rd edn. CRC Press, Taylor and Francis, Boca Raton

WHO (1997) Guidelines for drinking water quality, health criteria and other supporting information recommendations, 2nd edn. World Health Organization, Geneva

WHO (2009) Calcium and magnesium in drinking-water public health significance. World Health Organization, Geneva
WHO (2011) Guidelines for drinking water quality. World Health Organization, Geneva

Wilcox LV (1948) The quality of water for irrigation use. 962. U.S. Dept. of Agri- culture, Tech, Bull, Washington, DC, pp 1-40

Wilcox LV (1955) Classification and use of irrigation water. US Department of Agriculture, Washington, DC, p 969

Publisher's Note Springer Nature remains neutral with regard to jurisdictional claims in published maps and institutional affiliations. 